Georgetown University Law Center

Scholarship @ GEORGETOWN LAW

2015

\title{
Anti-Primacy: Sharing Power in American Corporations
}

Robert B. Thompson

Georgetown University Law Center, thompson@law.georgetown.edu

This paper can be downloaded free of charge from:

https://scholarship.law.georgetown.edu/facpub/1527

http://ssrn.com/abstract=2687218

This open-access article is brought to you by the Georgetown Law Library. Posted with permission of the author. Follow this and additional works at: https://scholarship.law.georgetown.edu/facpub

Part of the Business Organizations Law Commons 


\title{
Anti-Primacy: Sharing Power in American Corporations
}

\section{Robert B. Thompson*}

\begin{abstract}
Prominent theories of corporate governance frequently adopt primacy as an organizing theme. Shareholder primacy is the oldest and most used of this genre. Director primacy has grown dramatically, presenting in at least two distinct versions. A variety of alternatives have followed-primacy for CEOs, employees, creditors. All of these theories can't be right. This article asserts that none of them are. The alternative developed here is one of shared power among the three actors named in corporations statutes with judges tasked to keep all players in the game. The debunking part of the article demonstrates how the suggested parties lack legal or economic characteristics necessary for primacy. The prescriptive part of the article suggests that we can better understand the multiple uses of primacy if we recognize that law is not prescribing first principles for governance of firms, but rather providing a structure that works given the economic and business environment in place for modern corporations where there is separation of function and efficiencies of managers as a starting point. Thus the familiar statutory language putting all power in the board must be read against the reality of the discontinuous nature of the board (and shareholder) involvement in governance. Corporate governance documents of the largest American corporations, as discussed in the article, are consistent with this reality, assigning management to officers and using verbs like oversee, review and counsel as the director functions. The last part examines dispute resolution and the role of judges in such a world, with a particular focus on the shareholder/director boundary. At this boundary there are two distinct judicial roles, the traditional role focusing on use of fiduciary duty to check conflict and other director incapacity and the less-recognized role of protecting shareholder self-help. In this more modern context shareholders, because of market and economic developments, are able to effectively participate in governance in a way that wasn't practical three decades ago, when the key Delaware legal doctrines were taking root. What is particularly interesting here is how courts, commentators and institutional investors act in a way that is consistent with a shared approach to power, as opposed to the primacy of any of the theories initially suggested.
\end{abstract}

* Peter P. Weidenbruch Jr. Professor of Business Law, Georgetown University Law Center. Thanks to participants at the UCLA Conference and Micro-Symposium on Competing Theories of Corporate Governance, the 2015 Australian Corporate Law Teachers Conference and the Loyola Los Angeles faculty workshop and specifically to Norm Veasey, Russell Stevenson, Elizabeth Pollman, and Michael Guttentag for comments on earlier drafts and for research from Gareth McKibben and Paul Alexander from the Georgetown classes of 2014 and 2015. 


\section{Table of Contents}

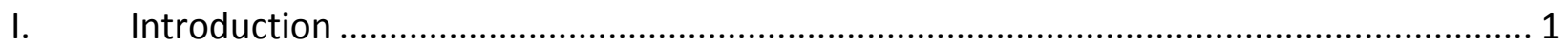

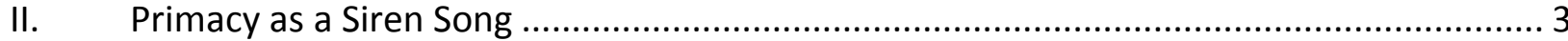

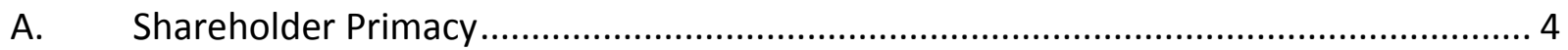

1. The two conceptions of modern shareholder primacy. ................................................ 5

2. The normative arguments as shaped by economic theories of the firm......................... 8

3. Shareholder primacy as really intended for something else ..........................................10

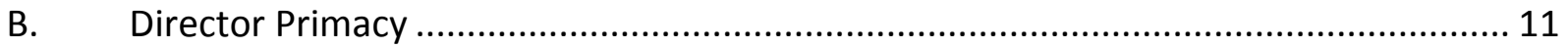

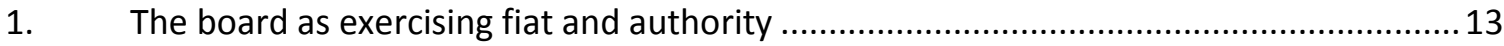

2. Directors as mediating hierarchs in a team production model .....................................14

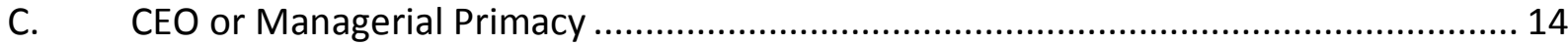

D. Other Primacy Theories, Including Employees and Creditors ................................... 16

III. A Non-Primacy View of Corporate Governance: Intentional Sharing of Power among Shareholders, Directors and Officers............................................................................ 18

A. Separation of Power Ideas Drawn from the Polity ................................................ 19

B. Shared Power Reflected in Corporations Statutes and Economic Realities ................ 20

1. The starting point of corporate governance: Economic reality makes managers the key decision-makers in a world of specialized inputs and large economic enterprises .........2. 21

2. Directors as policing agency costs of managers and as a source of additional information, or to be a mediating hierarch.

3. Shareholders' function to police agency costs, as a source of additional information, and to sometimes express preferences 23

4. Directors' actions to slow down shareholders' use of their power................................24

5. Dispute resolution by the parties themselves or by the courts as a referee ...................26

IV. The Role for Courts in a Non-Primacy Corporate Governance World .............................. 26

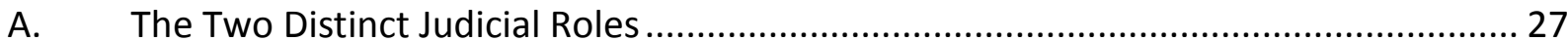

B. Speed Bumps in the Recognition of Shared Power ............................................... 30

1. Shareholder action by tender offer vs. voting

2. A sometimes judicial tendency to collapse judicial review of directors' action and shareholder self help

C. Judicial and Investor Acceptance of Shared Power ................................................... 35 


\section{Introduction}

Contemporary debates about the ends and means of corporate law have centered on concepts of primacy of one sort or another. The term is most often assigned to shareholders ${ }^{1}$ or directors $^{2}$ in a seeming duel for corporate power, but the principal protagonist is really management, usually assumed to have de facto power in modern American corporations. ${ }^{3}$ In turn, these labels have provoked a series of additional proposals suggesting primacy of other players, for example, employees ${ }^{4}$ or $_{\text {creditors. }}{ }^{5}$

The multiplicity of recipients to which primacy has been attached ought to suggest the limits of the explanatory power of any primacy theory. ${ }^{6}$ Their use to describe both ends and means makes it difficult to maintain any consistent theoretical approach. This article points instead to power-sharing among the three sets of actors named in all American corporations statutes-shareholders, directors and officers-each intentionally endowed to check the powers of the others and courts inserted as continuing facilitators of this mandatory power-sharing. This balance of power as to the means of exercising corporate power also is visible in the "ends" part of the debate. Corporate law's purpose is to provide a structure for private ordering within which a broad group of participants can contract for exchange and have available a governance structure to fill gaps. The shared power of shareholders, directors and managers, each checking the other, facilitates maximizing value of exchange in these relationships.

Part II examines the primacy arguments set out in its two most developed manifestations in corporate law and why neither is true. Shareholders play a crucial, but decidedly subordinate, role in corporate governance. Despite recurring references to shareholder primacy and to

${ }^{1}$ Henry Hansmann \& Reinier Kraakman, The End of History for Corporate Law, 83 GEO. L. J. 439, 440-41 (2001). A Westlaw search for "shareholder w/2 primacy" (as of July 30, 2014) produced 1201 hits in the Journals and Law Review data base, the earliest in the late 1980s, although as Part IIA describes the core ideas go back considerably further; a similar search for "director w/2 primacy" produced about half that - 586 and "manage! w/2 primacy" returned 90 hits.

2 Stephen M. Bainbridge, Director Primacy: The Means and Ends of Corporate Governance, 97 Nw. U. L. Rev. 547 (2003); Margaret M. Blair and Lynn A. Stout, A Team Production Theory of Corporate Law, 85 Va. L. Rev. 248 (1999).

${ }^{3}$ George W. Dent, Jr., Academics in Wonderland: The Team Production and Director Primacy Models of Corporate Governance, 44 Hous. L. REV. 1213, 1215 (2008) ("the status quo is not director primacy, shareholder primacy or team production, but CEO primacy, governance by managers largely for their own benefit. The interests not only of shareholders but other constituencies and the public would fare better with shareholder primacy"); William W. Bratton, Hedge Funds and Governance Targets, 95 GEO. L.J. 1375, 1476 (2007) (describing 20 th century managerialist that put corporate management at the large corporation's strategic center).

${ }^{4}$ Brett H. McDonnell, Employee Primacy, or Economics Meets Civic Republicanism at Work, 13 STAN. J.L. BUS. \& FIN. 334 (2008).

${ }^{5}$ Frederick Tung, The New Death of Contract: Creeping Corporate Fiduciary Duties for Creditors, 57 Emory L.J. 809 (2008) (using "contract primacy").

${ }^{6}$ See G. Mitu Gulati, William A. Klein \& Eric M. Zoltz, Connected Contracts, 47 UCLA L. Rev. 887, 947 (2000) (suggesting a model in which "there is no primacy, no core, no hierarchy, no prominent participant, no firm, no fiduciary duty"). 
shareholders as owners of the corporation, their power is not the plenary power of a primate or an owner, but rather limited to doing only three things - voting, selling, and suing-- and each in very limited doses. ${ }^{7}$

The strength of directors' powers is such that they are sometimes described in primacy terms. Yet the board is also a strange choice for a primacy role. Directors have little skin in the game and often have full-time work elsewhere. Their incentive structure, measured by compensation, share ownership, and other sources, is much more low-powered than that for managers, and their access to information is only a fraction of that available to officers. They are simply not in a position to manage a complex enterprise. The other primary theories get less attention here, but fare no better.

Part III presents the shared power alternative. The idea reflects some of the same motivations of the political choices found in our constitution-limits on the power of government and reliance on a balance of power in making those limits effective. But public corporations are different. In particular: (a) the separation of function with the specialization of efforts that follows if the modern corporation is going to deliver on its efficiency potential; and (b) the standard agency story from economics (and politics) as to risks that flow from that specialization when some actors end up with "power over vast aggregations of property that they do not own." 8

The practical reality in large public corporations is that managers make most corporate decisions, a direct result of the triumph of specialization and the efficiencies that come from it. Centralized managers in a hierarchy provide efficiencies in information gathering, decisionmaking and implementation that dispersed and numerous shareholders (or employees or creditors) simply cannot match. The statutory roles for directors and shareholders are structured in the shadow of that economic reality and only make sense from a starting point that presumes managers as the key (and initial) actors. In this sense the core purpose of corporations law is not to declare first principle as to the power of managers, shareholders, or directors, but rather to provide a governance system for a team of contributors that works in light of the benefits of specialization in large enterprises and the challenges of monitoring agents in that setting.

Directors police conflicts of the managers and sometimes share in the exercise of corporate power where they can bring additional information or perspective to the decision. In turn, shareholders police conflicts or laxness of the board, particularly if the board is captured by management, and occasionally participate in decisions where they can provide additional information or aggregate preferences of owners that may be different than managers. Those two legal effects are commonly accepted and well-understood, but another needs to be put alongside them that has been brought into focus in the current high profile debate as to the increased power of activist shareholders and the fear that their increased power is too shortterm focused in its use. Directors in addition to their key role in monitoring management have an additional role to slow down shareholders' use of their power because shareholders may

\footnotetext{
${ }^{7}$ Robert B. Thompson, Preemption and Federalism in Corporate Governance: Protecting Shareholder Rights to Vote, Sell, and Sue, 62 LAW \& CONTEMP. ProBs. 215 (1999).

${ }^{8}$ Blasius Indus., Inc. v. Atlas Corp., 564 A.2d 651, 659 (Del. Ch. 1988).
} 
sometimes be acting out of self-interest. And courts are given the power to resolve disputes where the power of the three groups intersect and are in conflict.

The result is a legal structure intentionally placed on top of a business and economic reality in which directors, managers, and shareholders are empowered to check the powers of each other with sometimes overlapping powers that provides space to interact with each other and work out a solution for the team. Part IV develops dispute resolution in such a structure with specific attention to how Delaware courts perform a referee role at the boundary where the powers of the groups meet. Delaware courts have long been director-centric in their approach, in ways that seem to leave little room for direct shareholder action. But they regularly have noted the need for a balance of power and their decisions illustrate a sensitivity to keeping the shareholders in the game with room for further negotiations among the parties. What is interesting about the most recent period is that the increased space for power to be exercised by shareholders has not come from changes in Delaware law but from market changes in makeup of the shareholder population and a nudge from federal regulations. But consistent with the recognition of the value of separation of power in achieving corporate purposes, activists have used this new space not to take absolute control of corporations, but rather to enhance and continue negotiations with directors over corporate policy.

\section{Primacy as a Siren Song}

Corporate governance in large and sophisticated modern American corporations involves so many parties that it might seem unlikely that any one of them could have primacy, but that has not dampened a still growing literature that sees clarity coming from attributing primacy to a particular corporate actor. ${ }^{9}$ The term is most often affixed to shareholders or directors, often as a way ostensibly to discredit the claims of the other. But even more confusing is that the real use of the primacy label given to each of those parties seems more directed to strengthening their ability to check a third set of actors in corporations-the officers who are its top managers-usually acknowledged to have de facto primacy in governance. This part first provides a context for shareholder and then director primacy, showing why each has developed and why neither is true. A subsequent section treats parallel primacy arguments for CEOs or others corporate players. The last section draws some generalizations as to why primacy has been so attractive to so many discussants of corporate law.

${ }^{9}$ The topic is also found in discussions of corporate governance globally - for example in the UK, Australia or the Nordic countries, see e.g. Malcolm Anderson, Meredith Jones, Shelley Marshall, Richard Mitchell \& Ian Ramsay, Shareholder Primacy and Directors' Duties: An Australian Perspective, 8 J. CORP. L. STUD. 161 (2008); John Armour, Simon Deakin \& Suzanne Konzelmann, Shareholder Primacy and the Trajectory of UK Corporate Governance, 41 BRIT. J. Of INDUS. REL. 531 (2003) (U.K.); Paul Krüger Andersen \& Evelyne J. B. Sórensen, The Principle of Shareholder Primacy in Company Law from a Nordic and European Regulatory Perspective, in THE EUROPEAN Financial Market in TRansition (Hanne Birkmose, Mette Neville \& Karsten Engsig Sórensen eds., 2011). 


\section{A. Shareholder Primacy}

Shareholder primacy frames two of the most long-running debates in corporate law. ${ }^{10}$ It is one side of a regulatory debate as to how to allocate decision-making power in the corporation, facing off in this context against management authority. The classic description is that provided by Berle and Means as to the separation of management and control in which the specialization of function in the modern corporation has given managers control of vast amount of assets contributed by others. ${ }^{11}$ Shareholder primacy is asserted to provide a means to redress that imbalance.

Shareholder primacy also defines one side of a vigorously contested debate about the purpose of the corporation. Here non-shareholder stakeholders provide the counter weight. Again Berle provides the classic frame, this time in his debate with Merle Dodd, in which Professor Berle argued for shareholders and Professor Dodd for the stakeholders as a way to insure a more public-regarding attitude of business. ${ }^{12}$ Other constituency statutes passed in the wake of the takeover rage of the 1980s illustrate a parallel stakeholder concern. ${ }^{13}$ Benefit corporations are a contemporary effort to permit other participants to limit the reach of shareholder primacy in corporations. ${ }^{14}$

These two contexts have been frequently noted, ${ }^{15}$ but the conflict they can create has received surprisingly little attention. Some discussions of shareholder primacy fit well-enough in either context but the two can work at cross-purposes as when empowering shareholders to restrain managers imposes costs on other stakeholders, so that it becomes important to identify which of the contexts in which primacy is being inserted.

Part of the difficulty of understanding shareholder primacy is that the concept, like the corporate form itself, has been used over two hundred years in a variety of relational contextsfrom a time in which there was little separation of function in a business enterprise and most

${ }^{10}$ D. Gordon Smith, The Shareholder Primacy Norm, 23 J. CoRP. L. 277 (1998). See also David Millon, Communitarians, Contractarians, and the Crisis in Corporate Law, 50 WASH. \& LEE L. REV. 1373, 1374 (1993) (clear that shareholder primacy has served as corporate law's governing norm for much of 20th century).

${ }^{11}$ Adolf A. Berle and Gardiner Means, The Modern Corporation And Private Property 119 (1933).

${ }^{12}$ Compare Adolf A. Berle, Jr., Corporate Powers as Powers in Trust, 44 HARV. L. Rev. 1049 (1931) with E. Merrick Dodd, For Whom Are Corporate Managers Trustees?, 45 HARV. L. REV. 1145 (1932).

${ }^{13}$ See e.g. Pa. Stat. Ann. Tit. $15 \$ 1715($ b) (Purdon) (“[D]irectors shall not be required...to regard any corporate interest or the interest of any particular group affected by such action as a dominant or controlling interest"); Cf. American Bar Association, Committee on Corporate Laws, Other Constituency Statutes: Potential for Confusion, 45 BUS. LAW. 2253, 2268 (1980) (permitting directors to consider other interests without relating such consideration in an appropriate fashion to shareholder welfare would conflict with directors' responsibility to shareholders and could undermine the effectiveness of the system that has made the corporation an effective device for the creation of jobs and wealth).

${ }^{14}$ See e.g. Del Code Ann. Tit. 8 \$361 et. seq. (2014). See generally, Jack Markel, A New Kind of Corporation to Harness the Power of Private Enterprise for Public Benefit, Huffington Post, July 22, 2013 (Delaware governor's statement that benefit corporations will "help combat the plague of short termism").

${ }^{15}$ Professor Bainbridge uses them to anchor his means/ends discussion. Bainbridge, supra note 2. 
firms were closely held, ${ }^{16}$ to industrial age enterprises in which separation was assumed but control often in a small group of investors, ${ }^{17}$ to the Berle and Means world of separation between owners and managers, to a world of hostile takeovers, and then to today's world of activist shareholders. The corporate form, and terms like primacy and shareholder wealth maximization, adapted to the various contexts in a manner that requires some effort to keep them all in an understandable perspective.

\section{The two conceptions of modern shareholder primacy.}

Henry Hansmann \& Reinier Kraakman, in their turn of the century pronouncement of the emergence of a standard model of corporate governance, ${ }^{18}$ captured the two core parts of the modern doctrine of shareholder primacy: shareholders' "ultimate control" over the corporation; ${ }^{19}$ and the managers' duty to put shareholders' interest first, ${ }^{20}$ often described as shareholder wealth maximization. ${ }^{21}$ The first suggests actual shareholder decision-making for the corporation, the second seems to acknowledge decision-making by others-boards or officers with shareholder wealth maximization used by courts to constrain that decision-making or internalized by corporate actors.

While some uses of shareholder primacy embrace both parts (and both would seem necessary if there is to be primacy in any realistic sense) often the primacy users are really talking

\footnotetext{
${ }^{16}$ See Smith, supra note 10 (discussing the $19^{\text {th }}$ century development of shareholder primacy and it roots in closely held enterprises; suggesting some skepticism about its jump to publicly held corporations and concluding "The shareholder primacy norm may be one of the most overrated doctrines in corporate law" Id at 322.)

${ }^{17}$ Cf James Willard Hurst, THE LeGITIMACY OF THE BUSINESS CORPORATION IN THE LAW OF THE UNITED STATES 17801970, at 76 (1970).

${ }^{18}$ Hansmann \& Kraakman, supra note 1.

${ }^{19}$ See John H. Matheson \& Brent A. Olson, Corporation Cooperation, Relationship Management and the Trialogical Imperative for Corporate Law, 78 Minn. L. Rev. 1443, 1461 (1994) (the traditional shareholder primacy model of the corporation derives from the concept that as owners of the corporation, shareholders are entirely to control its destiny, determine its fundamental policies and decide whether to make fundamental changes).

${ }^{20}$ These were the first two of the principal elements of the standard model of corporate government that Hansmann \& Kraakman found to have vanquished all competing theories. The others are that other corporate constituencies should have their interests protected by contract, nonmajoirity shareholders should receive strong protection and that the market value of publicly traded corporate shares is the principal measure of the shareholder interest. See Hansmann \& Kraakman, supra note 1, at 441.

Lyman Johnson \& David Millon provided a similar dichotomy at an earlier point distinguishing "shareholder protection" and "shareholder autonomy". See Lyman Johnson \& David Millon, Misreading the Williams Act, 87 Mich. L. Rev. 1862, 1882-86 (1989). The second usage was common after the passage of the Williams Act in 1968 and through the 1980s often in the context of an argument for federal preemption of state antitakeover law by "preserving for target shareholders the inviolable right to decide whether to accept tender offers" Id. The Supreme Court's 1987 decision in CTS Corp. v. Dynamics Corp. of America, 481 U.S. 69 (1987) rejected the preemption argument. In contrast to this earlier phrasing, this article focuses on shareholder self-help rights attributable to state corporations law. See David Millon, Radical Shareholder Primacy, 10 U. ST. THOMAS L. J. 1013 (2013) (offering a dichotomy of "radical shareholder primacy" and "traditional shareholder primacy.").

${ }^{21}$ See Bernard S. Sharfman, Enhancing the Efficiency of Board Decision Making: Lessons Learned from the Financial Crisis of 2008, 34 DEL. J. CORP. L. 813, 827 (2009).
} 
only about the second. ${ }^{22}$ There is a difference if primacy is limited only to this usage. Bainbridge, for example, clearly embraces shareholder wealth maximization and then makes that norm a foundation of his director primacy claim. ${ }^{23}$ It also makes a difference which of two variations of shareholder wealth maximization is meant: (a) the legal duty/judicial enforcement form that uses shareholder wealth maximization in filling out the meaning of fiduciary duty; or (b) the business school/mission statement form that shareholder wealth maximization is the proper purpose of the corporation. In the first it is left to the court to declare the parameters of shareholder primacy; in the second it is left to the business participants on the board in their decisions, business strategy or mission statement. In either, filtering shareholder primacy through actions by directors or officers or declarations by judges means the result is usually well short of what would usually be meant by primacy.

If the focus is on duty, what is important is how judges apply corporate law including the business judgment rule, widely acknowledged as a judicial rule of decision used to insulate director action from challenge by shareholders. Dodge $v$. Ford provides a classic example of this use of shareholder primacy. "A business corporation is organized and carried on primarily for the profit of its stockholders. The powers of directors are to be employed for that end...if the avowed purpose of the defendant directors was to sacrifice the interest of shareholders, it [would be] the duty of the courts to interfere." 24 There the Michigan Supreme Court ordered Henry Ford's Ford Motor Company to pay a large dividend to the shareholders of his then closely held corporation. ${ }^{25}$ Yet the court refused to interfere with management decisions to cut the price of its cars almost $20 \%$ when the company could sell every car coming off the assembly line at the higher price, a plan the court acknowledged would produce a less profitable company with "the apparent immediate effect...to diminish the value of shares and return to shareholders." ${ }^{26}$ The shareholder wealth maximization reasoning in that case extended only to requiring directors to pay dividends in the very unusual situation in which the corporation was already flush with cash, could internally finance a massive expansion while at the same time substantially reducing the price of its product, in a setting that was as close to being able to print money as a private company might find itself.

Revlon is another case frequently cited for director's duty to maximize shareholder profit. ${ }^{27}$ When a corporation is up for sale, the court declares the directors' duty as getting the best price for the stockholders. ${ }^{28}$ But subsequent case law made clear that this is well short of a

\footnotetext{
${ }^{22}$ See Smith, supra note 10, at278 ("it is within the law relating to fiduciary duty that shareholder primacy finds its most direct expression"); Lynn A. Stout, New Thinking On Shareholder Primacy, (UCLA School of Law, LawEcon Research Paper No. 11-04, 2011) available at http://ssrn.com/abstract=1763944.

${ }^{23}$ Stephen M. Bainbridge, Director Primacy: The Means and Ends of Corporate Governance, 97 NW. U. L. Rev. 547, 557-58 (2003).

${ }^{24}$ Dodge v. Ford Motor Co., 204 Mich. 459, 170 N.W. 668 (1919).

${ }^{25}$ The court described Henry Ford's testimony as creating the impression that he thinks "the Ford Motor Company has made too much money, has too large profits, and that although large profits might still be earned, a sharing of them with the public, by reducing the price of the output of the company, ought to be undertaken." Id at 683-4.

${ }^{26} / d$.

${ }^{27}$ Revlon, Inc. v. MacAndrews \& Forbes Holdings, Inc., 506 A.2d 173, 182 (Del. 1986).

${ }^{28} / d$.
} 
global duty in all takeover contexts. In Paramount $v$. Time where the target board rejected a cash bid of \$200 a share in favor of continuing an alternative combination whose value much less-- in the range of $\$ 120$ per share--, the Delaware Supreme Court declined to impose the higher scrutiny of asking if the board had gotten the best price. ${ }^{29}$ The trigger to get to "Revlonland" challenges law students and practitioners. ${ }^{30}$ Directors of a company looking at a takeover retain considerable flexibility in terms of structuring a transaction so as to avoid the Revlon duty of best price if they wish. ${ }^{31}$ This duty to maximize shareholder wealth is an obligation target directors can turn off or on depending on how they structure a transaction. Such shareholder primacy at the option of directors hardly seems to qualify for the name.

As identified above, shareholder wealth maximization is sometimes used in contexts outside judicial enforcement and it is worth separately examining the reach of this use in what might be termed its "mission statement" version. Lynn Stout observed that by 1990, most scholars, regulators and even many business practitioners had come to accept shareholder wealth maximization as the proper goal of corporate governance. ${ }^{32}$ Many of the largest American corporations, including, for example, Apple, Exxon, Berkshire Hathaway, and Google, publish principles of corporate governance saying that management power is to be exercised for the shareholders. $^{33}$ If these parties acting for the corporation believe and act on shareholder primacy, enforcement is secondary, if not unnecessary. But these documents provide a good bit of wiggle room. GE, for example, notes "Both the board of directors and management recognize

${ }^{29}$ Paramount Communications, Inc. v. Time, Inc., 571 A.2d 1140 (Del. 1990).

${ }^{30}$ In a subsequent case, the Delaware court applied the Revlon best price obligation to void defensive tactics inserted to protect a combination preferred by the board where, unlike Time, the acquiring company had a controlling shareholder. Paramount Communications, Inc. v. QVC Network, Inc., 637 A.2d 34 (Del. 1994) (focusing on the acquiring shareholder's loss of their only opportunity to share in a control premium). See also, Lyondell Chem. Co. v. Ryan, 970 A.2d 235 (Del. 2009) (noting that the trigger for Revlon is not a company being in play but rather embarking on a transaction - on its own initiative or in response to an unsolicited offer-- that will result in a change in control).

${ }^{31}$ For example, they can structure a deal to have the shareholders receive stock instead of cash and by avoiding a stock deal with a company having a controlling shareholder.

${ }^{32}$ Stout, supra at 22. But see Lyman Johnson, The Delaware Judiciary and the Meaning of Corporate Life and Corporate Law, 68 TEX. L. REV. 865, 877 (1990)-(“Most persons in this country probably would be astounded to hear that maximization of shareholder wealth is the reason d'etre of corporate existence.")

${ }^{33}$ The New York Stock Exchange listing standards require listed companies to adopt and disclose corporate governance guidelines. See www.nyse.com/lcm/lcm_sectiion.html §303A.09. All of the statements below are from governance principles set out on the company's website: Apple ("assures that the long-term interests of the shareholders are being served)

http://investor.apple.com/common/download/download.cfm?companyid=AAPL\&fileid=443011\&filekey=6a7d49f1 -a3af-4e69-b279-021b81a93cdf\&filename=governance_guidelines.pdf; Exxon ("the directors' fiduciary duty is to exercise their business judgment in the best interest of ExxonMobil's shareholders.") http://corporate.exxonmobil.com/en/investors/corporate-governance/corporate-governanceguidelines/guidelines; GE ("the board of directors is elected by the shareowners to oversee management and to assure that the long-term interest of the shareowners are being served.")

http://www.ge.com/sites/default/files/GE_governance_principles.pdf; Berkshire Hathaway, (On behalf of the Company's shareholders, the Board is responsible"); Google ("These corporate governance guidelines are established by the Board of Directors...to provide a structure within which our directors and management can effectively pursue Google's objectives for the benefit of its stockholders.")

https://investor.google.com/corporate/guidelines.html 
that the long-term interests of shareowners are advanced by responsibly addressing the concerns of other stakeholders and interested parties including employees, recruits, customers, suppliers, GE communities, government officials and the public at large." ${ }^{34}$ An earlier study by Lorsch and Maclver found widespread ambivalence among directors about shareholder primacy. ${ }^{35}$ With the breadth identified here and without enforcement, this use of shareholder wealth maximization provides some guidance and even accountability, but is a long way from primacy.

\section{The normative arguments as shaped by economic theories of the firm.}

The two most widespread theoretical arguments for shareholder primacy stem from economic learning developed in the mid-twentieth century. ${ }^{36}$ One thread draws on property rights and concepts of ownership and the other centers on agency costs. Milton Friedman's 1970 essay on the purpose of a corporation captures the property roots of shareholder primacy.

In a free enterprise, private-property system, a corporate executive is an employee of the owners of the business. He has direct responsibility to his employers. That responsibility is to conduct business in accordance with their desires, which generally will be to make as much money as possible while conforming to the basic rules of society. ${ }^{37}$

Stephen Bainbridge observed that "Because private property is such a profound part of the American ethos, this model's normative implications long dominated our approach to corporate law." ${ }^{38}$ Other economic-based scholarship focused not on ownership of the firm, but rather ownership of residual rights as supporting shareholder primacy. ${ }^{39}$ Easterbrook and Fischel, for example, have noted that shareholders have the appropriate incentives "to make discretionary decisions...The shareholders receive most of the marginal gains and incur most of the marginal costs. They therefore have the right incentives to exercise the discretion." 40

Neither variant reaches nearly far enough to support primacy. Financial theory has taught us that shareholders are not the only stakeholders with a claim to residual value. ${ }^{41}$ Options theory

${ }^{34}$ http://www.ge.com/sites/default/files/GE_governance_principles.pdf.

35 Jay Lorsch \& Elizabeth Maclver, PAWnS OR POTENTATES: THE REALITY OF AMERICAN CORPORATE BOARDS, 39-43 (1989) (majority of directors felt accountable to multiple constituencies; only a 'true minority adhere to a strict belief in the primacy of the shareholder.")

${ }^{36}$ Paul Edelman, Randall S. Thomas \& Robert B. Thompson, Shareholder Voting in an Age of Intermediary Capitalism, 87 S. CAL. L. REV. 1359 (2014).

${ }^{37}$ Milton Friedman, The Social Responsibility of Business Is to Increase Its Profits, N.Y. Times, September 13, $1970 \S 6$ (Magazine) at 32.

${ }^{38}$ Stephen M. Bainbridge, In Defense of the Shareholder Wealth Maximization Norm: A Reply to Professor Green, 50 WASH. \& LEE L. REV. 1423, 1428 (1993) (taking a contractarian view that firm is not capable of being owned and recommending throwing "Friedman's concept of ownership out the window, along with its associated economic and ethical baggage.").

${ }^{39}$ See, Eugen F. Fama \& Michael C. Jensen, Organizational Forms and investment Decisions, 14 J. FIN. ECON. 101, 102-03 (1985) (arguing that shareholders hold residual claims).

${ }^{40}$ Frank Easterbrook \& Daniel Fischel, The Economic Structure of Corporate LAW 68 (1991).

41 Frank Partnoy, Adding Derivatives to the Corporate Law Mix, 34 GA. L. REV 599 (2000). 
suggests that debt holders also have a claim on the residual value ${ }^{42}$ and parallel arguments can be made for other stakeholders. ${ }^{43}$

Even if these economic arguments were sufficiently consistent to provide a theory for primacy, the law flatly contradicts shareholder ability to make all "gap-filling" decisions for the firm or otherwise exercise rights accruing to residual owners to control the firm as does an owner in a sole proprietorship. ${ }^{44}$ Instead, corporations statutes provide that all corporate power is to be exercised by, or under the direction of, the board. ${ }^{45}$ Thus, shareholders cannot, as a rule, force the board to issue dividends to capture that value. ${ }^{46}$ Instead, shareholders' right to residual claims must be filtered through board decisions (e.g. the board's legal right to declare dividends, distribute assets, or dissolve) or through the market (by shareholders selling shares as the means to gain liquidity for their investment). ${ }^{47}$

Shareholder primacy also draws considerable strength from another foundational theory of modern law and economics-agency costs. Jensen and Meckling posit that the exchange of equity for capital establishes a principal-agent relationship between the shareholders and the board of directors. ${ }^{48}$ An agent, the board, will be tempted to extract private benefits using its control of the firm's assets and so the principals, the shareholders, must monitor the agent to protect their interests. When investors give up control of their assets to others as part a specialization of function within a firm, they will price what they seek for their contribution based on incentives of the managers to act for investors, the available monitoring of these agents tempted to extract private benefits, and the residual risk left in the agency relationship after those incentives or monitoring are put in place. Shareholder primacy provides such a monitoring mechanism. But as Bainbridge has pointed out, "this elegant theory breaks down precisely where it would be most useful...In general, shareholders of public corporations have neither the legal

42 Lynn A. Stout, Lecture and Commentary on the Social Responsibility of Corporate Entities: Bad, and NotSo-Bad Arguments for Shareholder Primacy, 75 S. CAL. L. REV. 1189, 1192 (2002).

43 Lynn Stout, The Shareholder Value Myth How Putting Shareholders First Harms Investors, Corporations and the Public, 41 (2012); Margaret M. Blair, OWNERSHIP AND CONTROL: ReTHINKING CoRPORATE GovernANCE FOR THE TWENTY-FIRST CENTURY 231 (1995).

${ }^{44}$ Easterbrook \& Fischel, supra note 4040, at 66.

45 See DEL. CODE ANN. tit. 8 §141(a) (2008) ("The business and affairs of every corporation organized under this chapter shall be managed by or under the direction of a board of directors..."); MODEL BUS. CORP. ACT §8.01(b) (2008) ("All corporate powers shall be exercised by or under the authority of, and the business and affairs of the corporation managed by or under the direction of, its board of directors...").

${ }^{46}$ Kamin v. Am. Express Co., 86 Misc. 2d 809, 383 N.Y.S.2d 807, aff'd, 54 A.D.2d 654, 387 N.Y.S.2d 993

(N.Y. App. 1st Dept. 1976) (applying business judgment rule and dismissing shareholder suit seeking to force the board to pay a dividend).

${ }^{47}$ Robert B. Thompson, Shareholder Power in the United States, in RESEARCH HANDBOOK ON SHAREHOLDER POWER (Randall Thomas \& Jennifer Hill, eds Edward Elgar 2015).

${ }^{48}$ Michael C. Jensen \& William H. Meckling. Theory of the Firm: Managerial Behavior, Agency Costs and Ownership Structure, 3 J. FIN.ECON:305, 312 (1976). This is a theoretical refinement of the Berle and Means' observation of the separation of ownership and control in the modern corporation. Adolf A. Berle \& Gardner Means, The Modern Corporation ANd PRIVATE PRoperty 119 (1933). 
right, the practical ability, nor the desire to exercise the kind of control necessary for meaningful monitoring of the corporation's agents." 49

Agency law (as distinguished from agency theory in economics) endows principals with a strong right of control and imposes fiduciary duties on agents that is consistent with the economic case for shareholder primacy. The American Law Institute's Restatement of Agency creates an agency relationship "when one person manifests assent to another person that the agent shall act on the principal's behalf and subject to the principal's control, and the agent manifests assent or otherwise consents so to act." ${ }^{\text {"50 }}$ Some courts have adopted a principal-agent frame in describing shareholders' power. ${ }^{51}$ Yet, American corporate law clearly refutes such a relationship. As already noted above, directors have the autonomous power to make virtually all business decisions under all the states' corporate statutes, which is difficult to reconcile with them being under the shareholders' "control." The Official Comment to the Restatement (Third) of Agency (following prior Restatements) states explicitly: "Although a corporation's shareholders elect its directors and may have the right to remove directors once elected, the directors are neither the shareholders' nor the corporation's agents as defined in this section, given the treatment of directors within contemporary corporate law in the United States." 52

\section{Shareholder primacy as really intended for something else}

As the discussion so far reveals, the theoretical arguments for shareholder primacy fall well short of giving shareholders ultimate control; corporate statutes provide rules that are flatly inconsistent with it and common law statements imposing a director duty to maximize shareholder wealth stop considerably short of universal application. Why then do we see such widespread use of the concept and such broad language? In one sense it may be a myth, as explored by Langevoort and others in the corporate setting, reflecting a need or desire to see the world as understandable or predictable and to avoid paralyzing contradiction. ${ }^{53}$ Kahan and Rock see something similar in the writings of New Dealer Thurman Arnold about corporate personification as a ritual that lets us live in contradiction: to let us accept the benefits of specialization and concentration of capital essential to realizing economics of scale and still hold on to traditional ideas like rugged individualism. ${ }^{54}$ Applying Thurman Arnold to today's corporate

49 Bainbridge, supra note 2 , at 568.

50 Restatement (Third) Of AgEnCy 17 (2006).

${ }^{51}$ Blasius Indus., Inc. v. Atlas Corp., 564 A.2d 651, 659 (Del. Ch. 1988) (Judicial review of board decisions alleged to interfere with the shareholder vote "involve the determination of the legal \& equitable obligations of an agent toward his principal.... [shareholders are entitled] to restrain their agents, the board, from acting for the principal purpose of thwarting" shareholder action.)

52 Restatement (Third) of Agency 29 (2006).

53 Donald C. Langevoort, Taking Myths Seriously: An Essay for Lawyers, 74 CHICAgo KeNT L. ReV. 1569,1576 (2000). See also Douglas Litowitz, The Corporation as God, 30 J. CORP. L. 501 (2005) (identifying a number of false myths at the core of corporate law including corporate democracy); Thomas W. Joo, Narrative, Myth \& Morality in Corporate Legal Theory, 2009 MICH. ST. L. REV. 1091, 1099--1101 (exploring theory and public choice explanations in how myths can move to "natural and inevitable"); Jonathan Macey, Sublime Myths: An Essay in Honor of the Shareholder Value Myth and the Tooth Fairy, 91 TEx. L. REV. 911 (2013).

${ }^{54}$ Marcel Kahan \& Edward Rock, Symbolic Corporate Governance Politics, 94 Boston U. L. REV. 1997, 2034 (2014). They also discuss other possible explanations such as seeking to affect a broader debate about larger 
governance they suggest "we need to believe shareholders control managers who control huge concentrations of capital." 55

It is possible, too, to over read primacy-that it is not intended so much as an absolute, but as a proxy for a relative change. Lucian Bebchuk, for example, talks not about primacy, but rather increasing shareholder power in a relative sense, which he advocates "to improve corporate performance and value." 56 Hansmann \& Kraakman disavow any intrinsic desire that corporations should be run in the interest of shareholders alone. "All thoughtful people" they tell us, believe corporations should be run for the interests of society as a whole; but as a consequence of logic and experience, they find a consensus that "the best means to that end is to make managers directly accountable only to shareholders." 57 To the extent that shareholder primacy devolves into an instrumental use of shareholder primacy and reflects a purpose to make managers accountable, the focus, as in Part III, should be on interactive balance of shareholders, directors and officers, more than a primacy-driven exercise.

\section{B. Director Primacy}

The argument for director primacy falls out a bit differently. Here the words of corporate statutes declare something that sounds like primacy. Delaware's General Corporations Law says "the business and affairs of every corporation... shall be managed by, or under the direction of "the board. ${ }^{58}$ The Model Business Corporation Act says the business and affairs of the corporation shall be managed by the board or under its direction and subject to its oversight. ${ }^{59}$

But facts on the ground belie this formal statement of director primacy. First directors lack the practical ability to be a primate. Theirs is a part-time job; they devote perhaps 20 hours a month on average, only a fraction of the time that officers and senior employees put in. ${ }^{60}$ There has been a move in recent decades to pay directors more and with stock that aligns their interest with shareholders, but they often can convert the stock into cash, and in toto their incentives are much less low-powered than those of the officers who are the real managers. ${ }^{61}$ The disparity

principles or various public choice explanations such as managers, lawyers or groups such as ISS using the debate for their own benefit.

55 Id.

${ }^{56}$ Lucian Arye Bebchuk, The Case for Increasing Shareholder Power, 118 HARV. L. REV. 833, 842 (2005).

${ }^{57}$ Hansmann \& Kraakman, supra note 1 at 444-449, (tracing fall of management, labor, state and stakeholder models).

58 Del. Code Ann. tit. 8, §141.

${ }^{59}$ Model Bus. Corp. Act. §8.01(b). Like Delaware, the Model Act includes "or under the direction of" as a permissible alternative to direct director management and in addition, includes "and subject to the oversight of" that the Official Comment suggests "operational management is delegated to executive officers and other professional managers."

${ }^{60}$ Lyman Johnson \& Robert Ricca, Reality Check on Officer Liability, 67 Bus. LAW. 75, 80 (2011) (citing studies showing increase in director time from 14 hours per month prior to Sarbanes-Oxley to about 20 hours through 2009); see also, Usha Rodrigues, A Conflict Primacy Model of the Public Board, 2013 U. ILL. L. REV. 1051, 1062 (2013).

${ }^{61}$ Katherine M. Brown, New Demands, Better Boards: Rethinking Director Compensation in an Era of Heightened Corporate Governance, 82 N.Y.U. L. REV. 1102, 1129 (2007) (criticizing equity compensation for directors). 
between directors and officers is more glaring on another key dimension to effective decisionmaking-access to information. Again the officers have much more access to the foundational data for decision-making than do their nominal superiors. ${ }^{62}$ To say that part-time directors with low-powered incentives and much less relative information are, in reality as distinct from legal doctrine, the primates in this governance structure is to engage in a fantasy.

American corporations recognize this reality. It has become common for large American corporations to develop, adopt, and publish on their website their principles of corporate governance that describe their internal structure. One of the largest 250 American companies described its allocation of authority this way: "all corporate authority resides in the board...the Board delegates authority to management to pursue the Company's mission. Management, not the Board, is responsible for managing the Company." 63 The document does allow that the Board retains specified responsibility to recommend Board candidates, to select, evaluate and terminate the CEO, and to advise management with respect to strategic plans, but that seems at some distance from primacy. It is an intermittent exercise of legal power-perhaps more commonly exercised than the shareholders' use of their legal power to elect and replace directors, but still decidedly intermittent in its use.. Our largest corporations suggest that their directors play a similar role. Microsoft's principles of corporate governance provide that "Shareholders elect the board to oversee management and to assure that shareholder long-term interests are served. Through oversight, review and counsel, the Board establishes and promotes Microsoft's business and organizational objections." 64 Chevron's document provides that the board "oversees and provides policy guidance on the business and affairs of the corporation."65 GE's guidelines say its business is "conducted by its employees, managers and officers, under the direction of the chief executive officer (CEO)) and the oversight of the board to enhance the longterm value of the company for its shareholders." 66 These are not verbs used to describe one exercising primacy. ${ }^{67}$

As a theoretical matter, board primacy has developed in two variants with substantially different implications for corporate governance. Steve Bainbridge draws on Kenneth Arrow and other threads of economic theory to argue for the value of authority and fiat in a manner that ends up being an argument for board sovereignty. ${ }^{68}$ Margaret Blair and Lynn Stout place director primacy within a team production theory where the board performs as a mediating hierarch. ${ }^{69}$

62 Rodrigues, supra note 60 at 1062.

63 Waste Management, Inc. Corporate Governance Guidelines available at http://investors.wm.com/phoenix.zhtml?c=119743\&p=irol-govhighlights.

${ }^{64}$ http://www.microsoft.com/investor/CorporateGovernance/PoliciesAndGuidelines/guidelines.aspx. Note the verbs used to describe the Board's roles- "Oversees" business affairs, "works with management to determine "strategy, "performs" the annual CEO evaluation, "oversees" succession planning and "oversees" internal controls.

65 See http://www.chevron.com/investors/corporategovernance/governanceguidelines/. The other verbs used with regard to the board's functions are to monitor overall corporate performance and "oversee" management and plans for successions of key executives.

${ }^{66} \mathrm{http}: / /$ www.ge.com/sites/default/files/GE_governance_principles.pdf.

${ }^{67}$ Stout, supra note 22, at 12.

68 Bainbridge, supra note 2, at 603.

${ }^{69}$ Blair \& Stout, supra note 2. 
This remainder of this section briefly summarizes each and examines the extent to which there is director primacy in the modern American corporation.

\section{The board as exercising fiat and authority}

Stephen Bainbridge has the more muscular of the two main director primacy arguments, making an affirmative case for the efficiency value of authority and the board being able to exercise fiat. Drawing from earlier work of Kenneth Arrow, Bainbridge sees fiat as the defining characteristic of corporate governance and its overarching value. ${ }^{70}$ The board executes fiat and its sovereign-like authority as part of an efficient decision-making system to reduce transaction costs associated with uncertainty, opportunism and complexity. ${ }^{71}$ This economic value of fiat means the boards should be viewed as acting for the entity to hire the various factors of production, rejecting a nexus of contracts approach to the corporation to the extent that it projects an entity with no primate.

Bainbridge, however, embraces, shareholder wealth maximization ("SWM"), as a core part of his director primacy. It becomes the critical means for accountability, a concept that under an Arrowian view is reciprocal to authority and in necessary tension with it, but which cannot occur to such a degree that it imperils authority. Given those limits, Bainbridge willingly turns to courts as the instrument to implement SWM as an accountability mechanism; he minimizes shareholder self-help via voting or probably other means that would illustrate the ultimate shareholder control prong of shareholder primacy. ${ }^{72}$ Indeed a key part of his director primacy argument is to counter shareholder primacy: Director primacy with its emphasis on authority and fiat provides a model for constraints on shareholder control under an efficiency justification. Even the control rights that he may concede to shareholders, such as the right to fire directors via the market for corporate control, he distinguishes from fiat, ${ }^{73}$ and in any event, he explains away any real effect from that potential: "In general shareholders of public corporations have neither the legal right, the practical ability, nor the desire to exercise the kind of control necessary for meaningful monitoring of the corporation's agents."74

The fiat that Bainbridge rightfully prizes is also characteristic of CEOs and management more generally. Indeed CEOs as a sole individual at the center of a management hierarchy, usually paid more than anyone else in the business, engrossed in the decisions of the business on a daily, hourly and sometimes instantaneous basis, are certainly better able to exercise fiat than a collective group, many with day jobs elsewhere, coming together only a few times a year (absent a crisis), with information very dependent on managers. Directors do retain the power to terminate, which they sometimes use and state law does provide them ultimate authority and requires that they approve some decisions such as mergers. ${ }^{75}$ But shareholders can replace

\footnotetext{
70 Bainbridge, supra note 2 , at 603.

${ }^{71} / d$. at 558 (Modern corporation's decision-making structure precisely fits Arrow's authority-based

72 Id. at 603-05 (so small as to be nonexistent).

$73 \mathrm{Id}$. at $570-71$ (the right to fire is not the right to exercise fiat-it is only the right to discipline).

74 Id. at 568 .

${ }^{75}$ Del Code Ann. tit. 8. §251(b).
} model). 
directors and shareholders must also give their consent for a merger to be effective. Given the reality of directors' use of their governing power can it really be said that directors have the "practical ability" or the "desire" to exercise control necessary for them to be considered a primate, even with the formal statutory authority given them? As developed in Part III, directors are a critical part of governance, but a primacy label put about their shoulders has too many ways to fall off.

\section{Directors as mediating hierarchs in a team production model}

Blair and Stout employ a director primacy model to solve a different problem than the fiat that drives Bainbridge. They see the corporation in a team production model where shareholders, employees, customers and local communities each make investments in the enterprise that are firm-specific where the inputs have particular value in this investment over some other use, and the return on the investment is not immediate, but at some point in the future. ${ }^{76}$ In such a setting the value of the investment, once made, can be appropriated by other participants who can behave opportunistically to renegotiate or threaten to withhold other inputs. Shareholders, like Ulysses of mythology, benefit from tying their own hands, so that other contributors will not decline to invest because of fear of misappropriation, which shareholders can do by ceding control to a mediating hierarch picked because the hierarch cannot personally profit. $^{77}$

The interactive governance of shareholders, directors and managers described in Part III has elements of team production, but the difference is not to leave all tie-breaking power in the hands of the board. The biggest challenge for a mediating hierarchs-based theory of corporate governance is that shareholders (and only shareholders) are empowered to replace the hierarch. How can you be a hierarch if one of the parties you are mediating between can kick you out? Blair and Stout do not spend a lot of time on this topic-it seems unimportant or nonexistent, perhaps in the way that Bainbridge sees the vote as so little used as to be capable of being ignored. ${ }^{78}$ But over the decade and a half since team production was published the large increase in shareholder power to throw out directors has made it much more difficult to ignore. The ability of shareholders to exercise something that looks like ultimate control of the board limits a primacy claim for directors so that this discussion fits better within a framework about shared power rather than one framed as director primacy.

\section{CEO or Managerial Primacy}

What may now be termed managerial primacy dominated much of $20^{\text {th }}$ century corporate law and management scholarship. ${ }^{79}$ Business advisor Peter Drucker noted that directors are

\footnotetext{
${ }^{76}$ Blair \& Stout, supra note 2.

77 Id at 272.

78 See infra note 72 .

${ }^{79}$ William W. Bratton, Jr., The New Economic Theory of the Firm: Critical Perspectives from History, 41
} STAN. L. REV. 1471, 1476 (1989) (20 ${ }^{\text {th }}$ century managerialism put corporate managers at the large corporation's strategic center); Alfred F. Conard, Beyond Managerialism: Investor Capitalism, 22 U. MICH. J. L. REF. 117, 120-130 (1988) (discussing managerialism). 
figureheads and shareholders are nonentities. ${ }^{80}$ Myles Mace in an extensive mid-century study of directors and governance concluded that presidents exercise de facto control and determine what directors do and don't do. ${ }^{81}$ Both Adolf Berle and Merle Dodd, who figured prominently in the earlier discussion of shareholder primacy, made managerialist assumptions. ${ }^{82}$

There has been both a positive and a negative aspect to discussion of managerial primacy, the former emphasizing the value that could arise from managerial primacy given economic conditions of the modern corporation, and the latter worried about the exercise of managerial power without sufficient accountability.

Alfred Chandler, in The Invisible Hand, describes the managerialist corporation of the $20^{\text {th }}$ century with administrative coordination that permitted greater productivity by lowering costs. ${ }^{83}$ William Bratton describes an unspoken bargain by which management would exchange stable dividends for their freedom to pursue growth; this growth bias left managers close enough to classical value maximizes for the system to be sufficiently value-creating and managers capable of statesmanship. ${ }^{84}$ Adolf Berle, at least after he saw the impact that the New Deal's social control over finance might have on management power, supported managerial power. ${ }^{85}$

Some recent discussions of CEO primacy, while acknowledging that CEOs control most corporations, add the normative view that this is largely for managers' own benefit and that society would do better with shareholder primacy or some other structure. ${ }^{86}$ Steven Ramirez has described this as dictatorship of management, by management, and for management and

80 Peter F. Drucker, CONCEPT OF THE CORPORATION 92 (rev. ed. 1972).

${ }^{81}$ Myles L. Mace, DiRECTORS: MYth AND REALITY (1971).

82 See Bratton, supra note 79.

${ }^{83}$ Alfred D. Chandler, Jr., The Visible Hand: The Managerial Revolution in American Business 1 (1977).

See also Michael C. Dorf \& Charles F. Sabel, A Constitution of Democratic Experimentalism, 98 CoLUM. L. REV. 267, 292 (1998) (discussing corporations that embodied an idea of efficiency as centralized, hierarchical and vertically integrated: "as long as these worked, these features were seen as expressing basic, incontrovertible, and mutually reinforcing principles of efficiency, governance, and cognition that became synonymous with effective human action"). Cf. Robert W. Gordon, Critical Legal Histories, 36 STAN. L. REV. 57, 83-85 (1984) (taking issue with Chandler's commitment to the determinism of "organizational imperatives" to the exclusion of cultural and social structure).

${ }^{84}$ Managers not motivated primarily by profit-seeking but by power, prestige and job security. Bratton, supra note 79 , at 1494 .

${ }^{85}$ As opposed to early Berle that pushed more for shareholder control. William W. Bratton \& Michael L. Wachter, Shareholder Primacy's Corporatist Origins: Adolf Berle and the Modern Corporation, 34 J. CORP. L. 99, 14044 (2008); William W. Bratton \& Michael L. Wachter, Tracking Berle's Footsteps: The Trail of The Modern Corporation's Last Chapter, 33 SEATTLE L. REV. 849 (2010) tracing Berle's move from the last chapter of Berle and Means when corporate managers emerged as 'neutral technocrats' who come to a state-directed negotiating table where they sit down with the state and other interest groups such as labor unions to determine the public interest to a post-war view of management as non-statist civil servants. "The shareholders, earlier thrown up against Dodd as a countervailing interest, dropped out of the governance picture." Id at 854, 856, 863.

${ }^{86}$ See George W. Dent, Jr., Academics in Wonderland: The Team Production and Director Primacy Models of Corporate Governance, 44 Hous. L. REV. 1213, 1215 (2008) ("the status quo is...CEO primacy, governance by managers largely for their own benefit"); id. at 1273 ("independent boards do not control most corporations now, CEOs do"). 
laments that "at every turn, legislators, judges, and regulators have eliminated or diluted constraints on the power of management." 87

Thomas Piketty provides a twenty-first century theoretical challenge to managerial primacy based on how much of the increase in societal inequality flows from the highest paid managers and their ability to set their own pay and extract rents from shareholders. ${ }^{88}$ Piketty notes that with the unique job functions at the top of corporations, individual managerial production becomes harder to define; given information and cognitive difficulties in that process, it is inevitable that the process yields decisions that are largely arbitrary and dependent on hierarchical relationships and the relative bargaining power of individuals. ${ }^{89}$

Thus, while managerial primacy remains widely accepted as a descriptive matter, few modern commentators provide a positive theory for its use and many criticize it. But there is not complete agreement about that descriptive story. Marcel Kahan and Ed Rock argue that CEOs have lost decision-making power through a combination of regulatory changes and shareholder activism. ${ }^{90}$ Measured in terms of decision-making power, second-guessing by shareholders and the board of directors, and the scope of CEO power, they see an embattled CEO. ${ }^{91}$ But as a normative matter in their ideal corporate governance world, centralized managers remain the important decision-makers: "boards would retain just that modicum of power that permits them to block, at the margin, more bad ideas than good ideas." 92 They acknowledge that it is "tough to know" whether we are at the point when the benefits of centralized control are maximized given agency costs such that the corporate governance debate becomes a search for the "sweet spot."93 Indeed, a common aspiration for many in the various parts of the primacy debate, including shareholder primacy discussed earlier, is the search for a parallel sweet spot in a shared power structure, as developed in Part III.

\section{Other Primacy Theories, Including Employees and Creditors}

Primacy theories in corporate governance have not been limited just to shareholders, directors, or managers. Fred Tung refers to a "host of new-fangled primacies [working] their way into the corporate law lexicon." 94 This section focuses on two, employees and creditors, to make two larger points. First, as Tung correctly positions almost all of the new-fangled primacies, they have developed most often to challenge or distinguish shareholder primacy, often within the economic or broader debate about the purpose of the corporation. Second, as we have already seen for parts of shareholder and managerial primacy, it is difficult not to stray from pure primacy

\footnotetext{
${ }^{87}$ Steven A. Ramirez, The Special Interest Race to CEO Primacy and the End of Corporate Governance Law, 32 DEL. J. CORP. L. 345, 367 (2007).

${ }^{88}$ Thomas Piketty, CAPITAL IN THE TWENTY-FIRST Century 206 (Arthur Goldhammer trans., Belknap Press)(2014).

${ }^{89}$ Id. at Chapter 9.

${ }^{90}$ Marcel Kahan \& Edward Rock, Embattled CEOs, 88 TEX. L. Rev. 987, 1007 (2010).

${ }^{91}$ Id. at 1039 (documenting, for example, the loss to shareholders and directors: "what has changed more than anything else is the ability and incentive for other players to second guess").

${ }^{92}$ Id. at 1049.

${ }^{93}$ Id. at 1051.

${ }^{94}$ Tung, supra note 5 at $817-18$.
} 
to a shared power but with greater recognition of the role of a particular group in realizing a stated purpose of the corporation.

Brett McDonnell, provides an effective illustration of the first point in his argument for employee primacy. ${ }^{95}$ He would insert employees in place of shareholders in both parts of the traditional description of shareholder primacy. Thus, he sees ultimate employee control over corporate decision-making and employee wealth maximization as the corporate objective. Employee primacy is likely to create more surplus given the strong incentives of employees and their relative wealth of information about the firm. ${ }^{96}$ More broadly he argues that employeeprimacy corporations are more likely to be socially responsible and, anticipating Piketty, less unequal in distribution of wealth. This, in turn, produces citizens better able to participate in political democracy.

Henry Hansmann, who has written in various settings about different aspects of worker participation in governance, ${ }^{97}$ suggests such a concept is most attractive when heterogeneity is less or the need for outside financing is less. ${ }^{98}$ The challenge of employee primacy as a primacy theory is to explain the various contexts when employees might have different interests from other constituents. In time of technological or market change when the firm or the economy cannot support the traditional level of wages, employee primacy may make it difficult for the firm to make adaptive decisions. Germany, and some other corporate governance systems in Europe, empower labor through a governance system of co-determination employing two corporate boards and specifying that employees are able to choose one half of the supervisory board. ${ }^{99}$ However, in Germany, which statutorily requires the existence of a supervisory board, legal rules do not necessarily result in employee empowerment that would suggest primacy. ${ }^{100}$ Hansmann notes that large German firms are often managed by a handful of shareholders who exercise control of the advisory board through coalitions and elections. The managing board, which must face reelection and the prospect of premature termination by the vote of the supervisory board, are by extension also affected by these shareholders. ${ }^{101}$ Co-determination today fills a smaller part in worldwide corporate governance than several decades ago, and even where it is used, it gives workers a veto from having half, but not more than half of the supervisory board, as opposed to outright control that primacy would suggest.

Creditor primacy arguments likewise seek to place another constituency into the position of shareholders in the shareholder primacy model, albeit in a space that is temporally limited.

${ }^{95}$ McDonnell, supra note 4.

${ }^{96}$ Id at 347-64.

${ }^{97}$ See Henry Hansmann, THE OWNERSHIP OF ENTERPRISE (1996); Henry Hansmann, When Does Workers Ownership Work? ESOPs, Law Firms, Codetermination, and Economic Democracy, 99 YALE L.J. 1749 (1990); Henry Hansmann, Worker Participation and Corporate Governance, 43 U. TORONTO L.J. 589 (1993).

${ }^{98}$ Hansmann, When Does Workers Ownership Work?, supra note 97 at 1783.

${ }^{99}$ Martin Gelter, The Dark Side of Shareholder Influence: Managerial Autonomy and Stakeholder Orientation in Comparative Corporate Governance, 50 HARV. INT'L L.J. 129, 158 (2009) (citing Section 76 of the German Stock Corporation Act which requires a supervisory board, elected by shareholder with half the board being employees, to monitor the management board).

$100 / d$. at 160.

${ }^{101} / d$. 
Here there is a longer history of judicial support for finding that director duties shift to creditors in times of financial distress. ${ }^{102}$ The substitution argument is fairly straightforward-where financial reversals or risks have left the company able to pay only some financial claimants but not all of them and the shareholder claim (the residual claim that would be paid last) has been wiped out, it no longer seems appropriate to have the directors responsive to shareholders' interest, but rather to the financial holders who still have skin in the game. ${ }^{103}$

While the creditors arguably have a strong claim to step into the shoes of shareholders in such a setting, they also inherit the same arguments that challenge a primacy position. Their claims are as similarly incomplete as those made against shareholders - neither may be the best residual claimants for some or all enterprises. ${ }^{104}$ The argument reduces to one of a more effective way to exercise control in particular circumstances ${ }^{105}$ with the larger theory more consistent with shared power than primacy.

\section{A Non-Primacy View of Corporate Governance: Intentional Sharing of Power among Shareholders, Directors and Officers}

As the previous part makes clear, primacy theory falls short as an accurate description of the role of shareholders or directors (or other parties) in the governance of modern American public corporations. This part suggests an alternative approach to governance based on intentionally-shared power among the three actors named in American corporations statutes: shareholders, directors, and officers. Such an approach is familiar to students of American public governance where separation of power has been engrained since the founding of the republic. This part first develops the antecedents of such a philosophy and how corporate governance reflects somewhat different needs and context. Subsequent sections develop how a shared power approach fits even within a statutory approach that puts all corporate power in the board and a legal/business environment that often explains the purpose of the corporation in terms of shareholder wealth maximization. The short answer is that law does not claim primacy for itself in terms of providing corporate governance rules, but rather recognizes the private bargaining and the market and economic realities that provide the foundation for corporate governance. Managers in the modern American public corporation provide hierarchy and efficiency, which permits officers to be the realistic starting point for corporate decisions; law structures its roles for directors and shareholders to reflect that reality. This section spells out in more detail how

102 Tung, supra note 5 (fairly settled); Jonathan C. Lipson, Directors' Duties to Creditors: Power Imbalance and the Financially Distressed Corporation, 50 UCLA L. REV. 1189 (2003); see Credit Lyonnais Bank Nederland, N.V. v. Pathe Communications Corp., No. 12150, 1991 Del. Ch. LEXIS 215 (Del. Ch. Dec. 30, 1991) (in the vicinity of insolvency).

103 See N. Am. Catholic Educ. Programming Fund, Inc. v. Gheewalla, 930 A.2d 92, 1101 (Del. 2007) (creditors of insolvent corporation have standing to make derivative claims against directors).

${ }^{104}$ Smith, supra note 10 . See also Lipson, supra note 102arguing not all creditors are equal with differences as to power imbalance, volition, cognition and ability to exit).

105 David Groshoff, Would "Junkholder Primacy" Reduce Junk Corporate Governance?, 13 J. BUS. \& SEC. L. 59, 117 (2012). 
the specific roles assigned to both shareholders and directors under statutory policy and prevailing governance theory parallel both economic and agency theory as to roles for the key players in the corporate governance setting.

\section{A. Separation of Power Ideas Drawn from the Polity}

Separation of power can be clearly seen in our public governance as a part of Madison's balance of power inserted into the structure of the constitution. ${ }^{106}$ Commentary on corporate governance suggests that "the degree to which we ought to push for government-like procedures and legitimacy is the most important policy or normative question that lies ahead in corporate governance." 107 For Madison the focus of balance of power was to produce "ambition designed to counter ambition." This policy of "supplying, by opposite or rival interests, the defect of better motives might be traced through the whole system of human affairs, private as well as public."108 Corporate writers frequently identify balance of power in the corporate form, as between, for example, boards and the CEO, ${ }^{109}$ shareholders and board, ${ }^{110}$ or between shareholders and management/directors. ${ }^{111}$

Yet any such balance was for decades mostly invisible as boards were quite deferential to managers without the separateness seen in the polity. Managers frequently voted themselves onto boards and shareholders rarely showed any kind of independence. ${ }^{112}$ The numerous checks and balances of government were absent in corporations, freeing managers of the type of accountability found in political decision-making. ${ }^{113}$ More importantly, the Madisonian principle of ambition countering ambition was in some ways "obviously unsuited to corporate governance....the corporation thrives on strong, flexible and adaptive leadership." Madison's checks and balances would supply the opposite "a tendency to produce impasse in decisionmaking that thwarts effective leadership."114 Yet separation of power, in a broader sense, remains a precondition for accountability in the corporate form that embraces hierarchy. ${ }^{115}$ Market and regulatory changes in the twenty-first century corporation have made separation and balance more realistic as a governance approach for these business entities. Independent directors, the expanded role for internal controls, and greater use of gatekeepers such as auditors

106 The Federalist No. 51 at 320 (James Madison).

${ }^{107}$ Cary Coglianese, Legitimacy and Corporate Governance, 32 DEL. J. CORP. L. 159, 167 (2007).

108 /d. at 159.

${ }^{109}$ Tamar Frankel, Corporate Boards of Directors: Advisors or Supervisors?, 77 U. CIN. L. REv. 501, 504 (2008).

110 J. W. Verret, Pandora's Ballot Box, or A Proxy with Moxie? Majority Voting, Corporate Ballot Access, and the Legend of Martin Lipton Re-Examined, 62 Bus. LAW. 1007, 1009 (2007).

${ }^{111}$ Coglianese, supra note 107, at 159.

112 ld.

${ }^{113}$ Edward D. Rogers, Striking the Wrong Balance: Constituency Statutes and Corporate Governance, 21 PePp. L. ReV. 777, 784 (1994).

${ }^{114}$ Michael E. Murphy, Restoring Trust in Corporate America: Toward A Republican Theory of Corporate Legitimacy, 5 N.Y.U. J. L. \& Bus. 415, 440-441 (2009).

${ }^{115} / d$. at 442 (emphasizing earlier non-Madisonian sense of separation of power as central to corporate self-regulation with deep roots in the republican tradition). 
and lawyers bolster public acceptance of the legitimacy of large American corporations that have an increasingly large publicness aspect. ${ }^{116}$

\section{B. Shared Power Reflected in Corporations Statutes and Economic Realities}

Corporate statutes specifically identify three parties for corporate governance rolesmanagers (officers), directors, and shareholders. ${ }^{117}$ Other stakeholders have interests in, and the ability to influence, corporate decisions, for example employees, suppliers, creditors, and affected communities. But their interactions usually occur via contracts, levers provided in market interactions, or regulatory actions, not structural claims to decision-making. Among the three named groups, managers make most corporate decisions, directors monitor that decisionmaking in a discontinuous way becoming involved particularly where there is a manager conflict, and shareholders monitor director decisions, albeit in an even more limited space.

This governance structure reflects a combination of positive law and private ordering of economic relationships, a structure that facilitates separation of function in the enterprise and the economic advantages that can come from that. If one looked only at the corporate statutes, governance would be described in director primacy terms, given statutes like Delaware §141 putting all power in the board backed up by the deference to director decision-making found in the business judgment rule that is heart of most judicial review in the corporate space. ${ }^{118}$ But directors delegate away most of their governance powers either expressly or by not interfering with management actions. And this pattern makes economic sense. In an enterprise taking advantage of specialization of function and the gains that can flow from that, managers devote more time to the enterprise, have more high-powered incentives to pay attention to corporate decisions and often more expertise in the industry. Directors practically limit their active decisions-making to matters where they have a relative advantage over managers, for example where managers have a conflict. Shareholder governance, as would be appropriate for a group specializing in providing capital, is limited to an even smaller number of decisions where directors may be conflicted or captured by management or shareholders have a different view on a fundamental question such as a takeover. ${ }^{119}$

As described in more detail in the remainder of this section the shared governance approach requires understanding how these core groups share power in a continuing interactive dance that reflects five core principles:

(1) Managers are the key decision-makers in corporate decisions, a point that reflects the influence of market and economic realities, more than a command from law;

116 Hillary A. Sale, The New "Public" Corporation, 2011 LAW \& CONTEMP. ProBS. at 137, 140; Coglianese, supra note 107.

117 See e.g. Mod. Bus. Corp. Act $\S \S 8.01$ (as to directors); 7.28 (as to shareholders); 8.40 (as to officers).

118 Robert B. Thompson, MERgers ANd ACQuisitions, LAW AND FINANCE (2d Ed. 2014)at 25 (describing "directors rule (most of the time)" as rule \# 1 of corporate law). See generally, Diane Holt Frankel et al., Proceedings of the 2014 Delaware Law Forum: "Director-Centric Governance" in the Golden Age of Shareholder Activism, 70 Bus. LAW. 707 (2015).

${ }^{119}$ Edelman et al., supra note 36 at $1378-84$. 
(2) Directors have broad legal power over corporate decisions but when viewed in the economic context of modern American public corporations, the directors' role is primarily one of monitoring managers;

(3) Shareholders, with a much more limited, but still powerful, space to act under corporate law, can use their powers to provide a monitoring role of the board and sometimes get to express decisional preferences reflecting their financial stake in the business;

(4) The board can use its broad powers to slow down the shareholders' use of their limited powers, an allocation that reflects a need to balance the value of shareholder monitoring of conflicted or captured directors against the possibility that shareholders monitors will sometimes be looking to use their limited power for selfish advantage;

(5) Friction among managers, boards and shareholders will regularly play out in recurring business interactions, but courts, particularly the Delaware courts, play a role to referee disputes arising out of exercise of power in the first four points, a context that requires additional elaboration in Part IV.

1. The starting point of corporate governance: Economic reality makes managers the key decision-makers in a world of specialized inputs and large economic enterprises

Managers make most corporate decisions in large American public corporations and have for almost all of the last century. This derives more from economics than law. Most state corporations statutes are virtually silent as the responsibilities of managers, in contrast to the more fulsome authority given to directors and shareholders. ${ }^{120}$ Instead, management power flows from the specialization of economic effort facilitated by the advances of the industrial age. Centralized managers in a hierarchy provide efficiencies in information gathering, decisionmaking, and implementation that autonomous small enterprises or larger entities organized via shared collective decision-making among numerous, dispersed participants simply cannot match on a recurring scale.

Law does not create or mandate this specialization, but statutes and judicial decisions based on fiduciary duty do provide a legal form that facilitates it. ${ }^{121}$ This illustrates the symbiotic relationship of law and markets in organizing human behavior. The purpose of corporations law is to provide a governance system that works in light of the benefits of specialization in large

120 Delaware has but one section on officers $(\$ 142)$ and the Model Business Corporation Act a short subchapter of five sections ( $\$ 8.40$ et seq.). In $21^{\text {st }}$ century legislation in response to financial crises, federal law has imposed significant new responsibilities on top officers, including to personally certifying quarterly financial reports and responsibility for internal controls. Federal law has done what state law has not-displaced the illusion of director control over management. See Robert B. Thompson \& Hillary A. Sale, Securities Fraud As Corporate Governance: Reflections Upon Federalism, 56 VAND. L. REV. 859, 861 (2003).

${ }^{121}$ See Charles R. T. O'Kelley \& Robert B. Thompson, CORPORATIONS AND OTHER BusinesS AsSOCIATIONS, CASES AND MATERIALS, ( $7^{\text {th }}$ Ed. 2014) at 149 (the corporate form can be used in entities where the same persons occupy the shareholder, director and officer positions-think close corporations-or the public corporation where participants desire to take full advantage of that specialization). 
enterprises such as the modern American public corporation, and the challenges of monitoring agents in that setting.

The corporate governance documents of large American public corporate quoted in Part II reflect this reality as do statements of observers of this governance system. Then Federal Reserve Board chairman Alan Greenspan, in the run-up to the passage of Sarbanes Oxley legislation in 2002, put the fulcrum of corporate governance squarely within the domain of the CEO not the directors: "the state of corporate governance to a very large extent reflects the character of the CEO."122

\section{Directors as policing agency costs of managers and as a source of additional information, or to be a mediating hierarch}

Only a small subset of corporate decisions-for example approval of fundamental changes such as mergers-actually requires board action that cannot be delegated to management ${ }^{123}$ and directors have reason not to exercise much of the authority they have. ${ }^{124}$ Corporate governance documents of large American public corporations, as discussed in the previous part, declare such intermittent, discontinuous director decision-making as their corporate policy. ${ }^{125}$ The obligation to pick and replace CEOs and approve executive compensation are relatively recent additions to the mandatory statutory list, but don't fundamentally alter the discontinuous nature of director decision-making. ${ }^{126}$

Director characteristics seem suited for such discontinuous duties. Their part-time status, usually with day-jobs outside the corporation, less high-powered incentives as compared to the CEO and other top managers and lack easy access to information about the enterprise all combine to limits their capacity to govern a large complex enterprise. . ${ }^{127}$ Corporate governance theory has long-recognized these realities. For more than four decades, the primary explanation for a board has been as a monitor. ${ }^{128}$ This is most evident in contexts where management has a conflict of interest or other loyalty problem, but can also include monitoring of decisions involving care in the management of the firm and risk management.

There are, of course, functions of directors other than monitoring. Mid-twentieth century description of board functions identified advising management as a key director function, providing management information and insights that otherwise might be missed. ${ }^{129}$ Boards,

${ }^{122}$ FRB-Statements and Speeches-Testimony of Chairman Alan Greenspan July 16, 20022009 WL 2815939.

${ }^{123}$ Mod. Bus. Corp. Act §11.04; Del Code Ann. tit. 8 §251(b) (directors must approve a plan of merger); $\S 261$ (same for sale of assets); §241 (proposals to amend articles).

${ }^{124}$ Adam Badawi, Influence Costs and the Scope of Board Authority, 39 J. CoRP. LaW 675 (2014) (board will intentionally decline to exercise much of their statutory power to avoid the disruptive effects from efficiency that would flow from the increase in mangers' effort to lobby the board that would follow).

${ }^{125}$ See text at note 63-66 supra.

126 ld.

127 See note 61 supra.

${ }^{128}$ See, Melvin A, Eisenberg, THE Structure Of THE Corporation (1976).

${ }^{129}$ Directors with expertise as to financing or industry knowledge might be expected to appear frequently on boards, but research shows that this is more likely to occur in firms controlled by private equity investors. See 
unlike management, act collectively by a group decision, often characterized by consensus. Having multiple decision-makers can lead to more information and arguably better decisions than one made by a single decision-maker where the answer is unknown but capable of a definitive answer. ${ }^{130}$ Boards continue to provide such an advising and information function, but on a much reduced scale than these earlier descriptions might have suggested. ${ }^{131}$

Blair and Stout's team production model sees the value of the board in offering assurance to providers of firm-specific assets that decisions about the use of those assets will be made a neutral decision-maker less likely to have incentives that would distort a firm-efficient decision. ${ }^{132}$ The effectiveness of this board function turns on how often directors would mediate when managers would not and how often other constituencies would discount directors' likelihood of not being sufficiently active to protect their interests.

\section{Shareholders' function to police agency costs, as a source of additional information, and to sometimes express preferences}

Shareholders' authority by statute can only be exercised in an even more discontinuous basis than the board's authority. Their power, too, is best explained in monitoring terms, but can also be supported by some information explanations or in the value of decision-making by the parties who have more at risk than the prior two decision-makers. By law, shareholders can only do a few things:

- Elect/remove directors; ${ }^{133}$

- Approve fundamental corporate changes such as mergers but only after those changes have been proposed to them by the directors; ${ }^{134}$

- Amend bylaws (also a power given to directors; shareholder can't use this authority to intrude into director authority to manage the corporation); ${ }^{135}$

- Sell their shares, which becomes a governance tool in the context of tendering to a bidder seeking to acquire control to move the corporation in a different direction; ${ }^{136}$

- Derivative suits or other litigation usually to trigger judicial review of director decision-making; ${ }^{137}$ and

Ronald W. Masulis \& Randall S. Thomas, Does Private Equity Create Wealth? The Effects of Private Equity and Derivatives on Corporate Governance, 76 U. CHICAGO. L. REV. 219 (2009).

${ }^{130}$ See Paul H. Edelman, On Legal Interpretations of the Condorcet Jury Theorem, 31 J. LEGAL STUD. 327, 328 (2002).

${ }^{131}$ Rodrigues, supra note 60 at 1054-55.

132 Blair \& Stout, supra note 2.

133 MOD. Bus. CORP. ACT §7.28.

134 MOD. Bus. CORP. ACT § 11.04.

135 MOD. BUS. CORP. ACT $\S 10.20$.

${ }^{136}$ The right to sell is not typically in corporations statutes but rather flows from basic property rights to transfer property. See Blasius Indus., Inc. v. Atlas Corp., 564 A.2d 651, 659 (Del. Ch. 1988)(“Generally, shareholders have only two protections against perceived inadequate business performance. They may sell their stock (which, if done in sufficient numbers, may so affect security prices as to create an incentive for altered managerial performance), or they may vote to replace incumbent board members.")

1378 Del. Code Ann. tit.8 §109(a). 
- Inspect certain corporate records. ${ }^{138}$

Millon describes such voting and informational rights as vestiges of an older age when shareholders, like partners, controlled their firms. ${ }^{139}$ Perhaps that also explains Bainbridge's dismissal of shareholder voting and Blair \& Stout's passing fairly quickly over that issue aside. ${ }^{140}$ But it seems too cavalier to ignore so much of corporate law, particularly in a current setting where economic and market conditions have facilitated the use of these governance rights.

The principal governance use of these powers in modern American corporations is a monitoring function similar to that just discussed for directors. Shareholders can monitor directors most often when the directors are conflicted or are captured by management. In earlier period of corporate law such shareholder rights were described as serving to protect shareholder property rights in ownership interests of the enterprise. ${ }^{141}$ It can still be argued that including shareholders in the decision-making provides an informational advantage to the decision in certain contexts. ${ }^{142}$ But the most viable and recurring use of shareholder power is to address conflict of interest that flows from the separation of power already discussed when the board itself is tainted by the conflict or too close to management so as to be incapable of effectively providing the necessary policing.

\section{Directors' actions to slow down shareholders' use of their power}

The first three principles are generally understood and longstanding in discussions of corporate governance, but this fourth one is of more recent vintage and subject to a vigorous debate. The need for a principle like this, however, is obvious given first three. As Dr. Seuss told us, if we need and employ a "bee-watcher", we will then need a "bee-watcher-watcher" and so on and so on. ${ }^{143}$ The corporate law solution is a bit more nuanced, if less rhythmic. The shareholders can monitor the board, but what (or who) is to keep them from using their power in way that harm other constituents, for example to elect directors who will declare large dividends or to empower a buyer to prefer short term profit maximization. ${ }^{144}$ In cases like

${ }^{138}$ Del. Code Ann. tit. 8 §220; Mod. Bus. Corp. Act, chapter 16.

139 Millon supra note 20 at 1025, 1044.

140 See earlier discussion in the text at note 72.

141 Bayless Manning, The Shareholder's Appraisal Remedy: An Essay for Frank Coker, 72 YALE L.J. 223, 22731 (1962).

142 Edelman, Thomas, \& Thompson, supra note 36, at 1378.

${ }^{143}$ Dr. Seuss, Did I EVer Tell You How Lucky You ARE? (Random House 1973) (“Out west near HawtchHawtch there's a Hawtch-Hawtcher bee watcher, his job is to watch. Is to keep both his eyes on the lazy town bee, a bee that is watched will work harder you see. So he watched and he watched, but in spite of his watch that bee didn't work any harder not mawtch. So then somebody said "Our old bee-watching man just isn't bee watching as hard as he can, he ought to be watched by another Hawtch-Hawtcher! The thing that we need is a bee-watcherwatcher!". Well, the bee-watcher-watcher watched the bee-watcher. He didn't watch well so another HawtchHawtcher had to come in as a watch-watcher-watcher!")

${ }^{144}$ Leo B. Strine, Jr., Toward a Corporate Republic: A Traditionalist Response to Bebchuk's Solution for Improving Corporate America, 119 HARV. L. REV. 1759, 1783 (2006) ("a continued preoccupation solely with management's flaws ignores the reality that the growing influence of institutional investors during the last quarter century has not be an unadulterated good.") 
Unitrin, the court emphasized the potential for shareholders to act out of ignorance, ${ }^{145}$ perhaps to take a deal with "hot" money, but the debate has moved from ignorance to encompass the fear that shareholders will more directly seek to implement strategies that benefit their own investment preferences at the expense of other constituents. ${ }^{146}$ The need now is to separate value-enhancing monitoring by shareholders from rent seeking. While it would be possible to impose fiduciary duties on shareholders, that would be messy and perhaps incomplete. Courts to this point have preferred to work this out within the space of judicial review of director power as in Blasius. ${ }^{147}$ We let the board use its $\S \S 8.01 / 141$ powers to slow down the shareholders' use of their "ultimate" powers, thus requiring shareholders and directors/managers to continue to talk to one another much like the divided branches of our government push back and forth, trying this or that, until they find a result that each can live with, or lets each live to fight another day with neither group getting to exercise absolute power.

This recognition of shared power was slow to get to corporate law. As previously described shareholders have only very limited statutory or market-based powers and for most of the last century economic and market conditions were such that it was seldom worthwhile for any shareholder to actively pursue use of these rights. The "Wall Street Rule" was by far the dominant shareholder response-if you didn't like the way things were going, selling via the market was the only realistic strategy. But the $21^{\text {st }}$ century has seen the emergence of a different governance world. Shareholders are now institutions, rather than mom and pop individuals, often with greater economic sophistication and larger economic stakes to support their investment position. Greater computing power has facilitated their ability to gather information and lowered the costs of communicating among like-situated investors. Institutional investors, particularly hedge funds, have developed an effective strategy to make shareholder activism pay. The government now requires many institutional investors to vote the shares they hold for beneficial owners such as those in retirement plans and powerful proxy advisors, such as Institutional Shareholder Services, have grown up to advise them and have become powerful players in corporate governance. ${ }^{148}$ This greater activism by shareholders has challenged

145 Unitrin, Inc. v. Am. Gen. Corp., 651 A.2d 1361 (Del. 1995).

${ }^{146}$ See Martin Lipton, Just Say No, The Harvard Law School Forum on Corporate Governance and Financial Regulation (Dec. 5, 2014, 9:17 AM) available at

http://www.wlrk.com/webdocs/wlrknew/AttorneyPubs/WLRK.23687.14.pdf.

147 Leo B. Strine, Jr., If Corporate Action is Lawful, Presumably There Are Circumstances In Which It Is Equitable to Take That Action: The Implicit Corollary to the Rule of Schnell v. Chris-Craft, 60 Bus. LAW. 877, $893,(2005)$ ("though Blasius obviously taught boards and their advisors that they must be very careful in the election context, [it] left it open to them to act so long as they were prepared to justify, in a situationally specific way, their behavior. In other words, whether or not it can be argued that the Atlas board's actions were wrongly set aside by the Blasius decision, that decision did not totally inhibit future conduct, as the subsequent cases applying Blasius demonstrate.")

On the larger point of the particular ability of judges, as compared to legislatures and markets, to produce legal rules that protect shareholder interests, see Jill E. Fisch, The Peculiar Role of the Delaware Courts in the Competition for Corporate Charters, 68 U. CIN. L. REV. 1061, 1086-96 (2000).

${ }^{148}$ For a discussion of these trends, see Ronald J. Gilson \& Jeffrey N. Gordon, The Agency Costs of Agency Capitalism: Activist Investors and the Revaluation of Governance Rights, 113 CoLUM. L. REV. 863, 897 (2013); Paul Edelman, Randall S. Thomas \& Robert B. Thompson, Shareholder Voting in an Age of Intermediary Capitalism, 87 S. CAL. L. REV. 1359 (2014). 
management in a way not seen since the "raider" period of the pre-Williams Act years. ${ }^{149}$ Directors' ability to slow down shareholder action has been part of a larger debate about whether shareholder activism is good for corporations and society..$^{150}$

\section{Dispute resolution by the parties themselves or by the courts as a referee}

What should be the role of courts in this governance structure of intentionally shared authority among management, directors and shareholders with each empowered to balance the other? Sometimes disputes between these players will get worked out by private ordering among these parties, but it should not be surprising that courts have a role in these disputes. Of course, courts are not the only possible dispute resolution mechanism; a government regulator could work out the allocation of power. In some common law countries, it is common for shareholder-director disputes in a mergers context to be put to a Takeovers Panel, often made up of industry experts and participants and perhaps some government officials. ${ }^{151}$ But in the United States, this role of resolving disputes between shareholders and directors, particularly as to those of the type of point \# 4 above, have been left to the courts, and most particularly to the Delaware courts, a context that is addressed in more detail in Part IV.

\section{The Role for Courts in a Non-Primacy Corporate Governance World}

When governance powers are split among different groups as in modern corporations, disputes can be expected to arise at the boundary where each group's rights and interest intersect with others. The American corporate law structure gives courts the principal role at these boundaries, particularly at the boundary of shareholder and director authority.

When stakeholders other than the three named in corporate statutes raise corporate governance issues, the judicial role is typically limited to interpreting contracts or applying regulatory rights found in more general laws outside of the corporations statutes. The absence of a structural role for these players in corporate law limits the judicial involvement in these settings.

Even within the three named groups, if the dispute is between managers and directors, there will be almost no judicial involvement. Managers will make most decisions ostensibly under the direction of the board. The board retains the legal authority to overturn every decision management makes, but realistically holds for itself only a small subset of corporate decisions. But if board does override the management, there is little legal basis for management to seek judicial intervention to reverse the decision. Management will look to non-judicial channels to address their concerns about director actions. ${ }^{152}$ This ends up being less of a legal boundary

${ }^{149}$ See 15 U.S.C. $\S 78 \mathrm{~m}(\mathrm{~d})(2006)$

150 See Lipton, supra note 146.

151 John Armour \& David A. Skeel, Jr., Who Writes the Rules for Hostile Takeovers, and Why?-The Peculiar Divergence of U.S. and U.K. Takeover Regulation, 95 GEO. L.J. 1727, 1744-45 (2007).

${ }^{152}$ Adam Badawi, supra note Error! Bookmark not defined., (describing how managers with more intense preferences given undiversified human capital and typically high powered incentives will lobby the board as to possible board actions that may intrude on management decisions which may hurt firm efficiency; boards will 
policed by the court but rather one where relationships are left to economic and market relationships.

At the shareholder/director boundary things are more active. Here there are two distinct judicial roles. The first, ordinary director action fiduciary duty claims, arises when an individual shareholder (no collective action is required) goes to court alleging that directors or managers breached their fiduciary duty (e.g. conflict, lack of good faith, or due care). ${ }^{153}$ This has long been a core part of American corporate law and is the most common way that courts are involved in corporate governance. Judges are tasked to decide whether director and manager actions meet long-established standards of care and loyalty for one who has control of the property of another. ${ }^{154}$ The second, shareholder self-help claims, arises when shareholders assert the affirmative authority to act collectively themselves, usually contrary to the board's preferences. ${ }^{155}$

\section{A. The Two Distinct Judicial Roles}

The judicial role is different in these two settings just described. In the ordinary director action fiduciary duty context, the core issue is whether judges should displace director decisionmaking. Courts regularly acknowledge it is neither their role nor their expertise to make business decisions. ${ }^{156}$ Judges feel comfortable evaluating conflict and process that can destroy a fiduciary's capacity to act for the entity, but stay away from the substance of business decisions. The broad control over other peoples' money given to boards and management by corporate statutes has long been understood to trigger fiduciary duties by those parties. Individual shareholders can file suit in the name of the corporation or a class of shareholders alleging breach of such duties. ${ }^{157}$ Judges rule on these claims following a well-defined path: the beginning point is one of deference; courts will defer to the business judgment unless plaintiff shows something such as conflict, gross negligence, bad faith, fraud, illegality, or waste. ${ }^{158}$ Upon such a showing, the court will move off of deference to a more intrusive review of the challenged act under an entire fairness or other standard. The focus here is on the board's (or management's) domain. In particular, courts focus on whether there is some reason or disability so that the board or managers have lost the capacity to act. Courts are quick to distinguish such failures from judicial interference with the insiders' business judgments. ${ }^{159}$

In the shareholder self-help context the governance question is broader. It is not just a question of whether a judge should decline to defer to director decision-making because of

intentionally decline to exercise all (or most) of the power given to them by corporate statutes to avoid being subject to more lobbying by managers .)

153 See supra Part IIIB3.

${ }^{154}$ Restatement (Third) Agency $§ 1.01$.

155 See e.g. the first of the powers itemized at Part IIIB3 that reflect the limited space in which positive law authorizes shareholders to act.

156 See e.g. Shlensky v. Wrigley, 237 N.E.2d 776, 779 (III. App. 1968).

157 Aronson v. Lewis, 473 A.2d 805, 811 (Del. 1984).

158 Mergers supra note 118 at 97.

159 Shlensky v. Wrigley, 237 N.E.2d 776 (III. App. 1968); Paramount Communications, Inc. v. Time, Inc., 571 A.2d 1140 (Del. 1990). 
conflict or insufficient process or another deficiency, but whether shareholders as a matter of governance should supplant the directors and be the decision-makers for the corporation even if there is no conflict or other deficiency. ${ }^{160}$ It is possible to use the language of the ordinary director action fiduciary duty context to resolve shareholder self-help claims; Delaware courts in developing enhanced judicial review under Unocal and Revlon frequently discuss the conflict of directors of a target company when taking defensive tactics to fend off an unwanted takeover. ${ }^{161}$ The result may be to invalidate action taken by such boards that interfere with shareholder actions. But that approach gives short shrift to the distinctive governance question posed in a self-help context and how it is different from the ordinary fiduciary duty context. The first tasks courts to use fiduciary duty to protect shareholders against director or management action that does not meet traditional standards of loyalty or care and the second to leave room for shareholder self-help as an independent component of governance.

The two different kinds of judicial roles just described correspond to the dichotomy in the versions of shareholder primacy discussed in Part II. Ordinary director action fiduciary duty corresponds to the older and more established version of shareholder primacy linked to the purpose of the corporation and focused on how courts ought to define that purpose of the corporation in interpreting director fiduciary duty. ${ }^{162}$ It also reflects the core of Bainbridge's director primacy view that is so focused on broad director authority so long as courts can use fiduciary duty with a strong shareholder wealth maximization norm to rein in director action. ${ }^{163}$ Shareholder self-help corresponds to the younger variant of shareholder primacy that extends to permit shareholders to act on their own as a recognized part of corporate governance. ${ }^{164}$ As set out in Part II, none of the primacy approaches have sufficient descriptive power alone to be the foundation of corporate governance theory, but this recognition of the two distinct ways in which director-shareholder roles are addressed in corporate governance contributes to the a separation of power understanding of corporate governance.

This difference between the two distinct roles that judges are called on to perform is also reflected in judicial decisions and academic writings beyond primacy. The Delaware Supreme Court, for example, has distinguished enterprise from ownership decisions ${ }^{165}$ as have writers in

${ }^{160}$ Blasius Indus., Inc. v. Atlas Corp., 564 A.2d 651, 658-59 (Del. Ch. 1988) ("The real question the case presents, to my mind, is whether, in these circumstances, the board, even if it is acting with subjective good faith (which will typically, if not always, be a contestable or debatable judicial conclusion), may validly act for the principal purpose of preventing the shareholders from electing a majority of new directors. The question thus posed is not one of intentional wrong (or even negligence), but one of authority as between the fiduciary and the beneficiary (not simply legal authority, i.e., as between the fiduciary and the world at large.")).

161 Unocal Corp. v. Mesa Petroleum Co., 493 A.2d 946, 953-56 (Del. 1985); Revlon, Inc. v. MacAndrews \& Forbes Holdings, Inc., 506 A.2d 173, 180 (Del. 1986) (the "omnipresent specter that a board may primarily be acting in its own interest rather than those of the corporation or its shareholders.")

162 Smith, supra note 10.

163 Bainbridge, supra note 2.

164 Johnson \& Millon, supra note 20.

165 Omnicare, Inc. v. NSC Healthcare, Inc., 818 A.2d 918, 930 (Del. 2003) See also Blasius indus. Inc. v. Atlas Corp., 564 A.2d 651 (discussing shareholder ownerships rights); William Allen, Jack Jacobs \& Leo Strine, Function Over Form: A Reassessment of Standards of Review in Delaware Corporation Law, 26 DEL. J. CORP. L. 859, 886 (2001) (noting that Blasius was a "ringing endorsement" of the need for protection of shareholder rights and 
law reviews. ${ }^{166}$ Former Securities and Exchange Commissioner Troy Paredes has made a parallel distinction between managerial control and residual control that picks up on similar themes:

The board (and the officers to whom the board delegates authority) ultimately exercises managerial control, subject to the shareholders' residual control rights over the enterprise. Most notably, shareholders have the right to elect and remove directors, but they also have the right to sell. Shareholders have the right to sell their shares when they disapprove of the way the board and the management team are running the company or for any other reason. Not only do individual shareholders have the right to sell their shares in the company, but, at least as a default matter, shareholders have the right to sell their shares collectively so as to transfer control of the company, in effect retracting the board's control. Indeed, alienability is typically understood to be a key feature of one's property rights. ${ }^{167}$

At the same time, Delaware courts have avoided any clear statement on shareholderversus director-primacy. Certainly their rulings on poison pills and other takeover contexts reflect their long-standing adherence to a corporate governance system in which their Rule \#1 is to trust directors to make business decisions. ${ }^{168}$ But their jurisprudence clearly requires room for shareholder decision-making. Together these two strands cannot support a pure form of shareholder or director primacy. Indeed, the Delaware Supreme Court has noted the express

that post Blasius cases have recognized the reality that some sorting mechanism needed to insulate from Blasius director actions "consistent with their legitimate authority.")

166 That distinction reflects earlier writing by a Delaware chief justice in a law review about enterprise and ownership decisions, E. Norman Veasey, The Defining Tension in Corporate Governance in America, 52 Bus. LAW. 393, 394 (1997) (Ownership issues may sometimes implicate the traditional business judgment rule, but often ownership decisions recognize an enhanced court scrutiny that goes beyond the traditional rule). This, in turn, draws on writing by a distinguished academic of an earlier generation: Bayless Manning, Reflections and Practical Tips on Life in the Boardroom After Van Gorkom, 41 Bus. LAW. 1, 5-6 (1985) ("one may predict that the standards of stringency of care (and loyalty) that will be applied by courts with respect to the business judgment rule will differentiate across a spectrum between 'enterprise' issues and 'ownership claim issues.)

167 Troy A. Paredes, The Firm and the Nature of Control: Toward a Theory of Takeover Law, 29 J. CORP. L. 103,121 (2003); The sources Parades cites are relevant to the balancing described here: See Larry E. Ribstein, Takeover Defenses and the Corporate Contract, 78 GEO. L.J. 71, 79, 80-81 (1989) (stating that "[t]he shareholders' power to transfer control is as important a part of the standard form contract in public corporations as their power to vote on corporate transactions and to elect and remove directors"); Stephen M. Bainbridge, The Board of Directors as Nexus of Contracts: A Critique of Gulati, Klein \& Zolt's "Connected Contracts" Model, UCLA School of Law, Research Paper No. 02-05, 2002, available at http:// papers.ssrn.com/abstract=299743 at 4 n.11; Leo E. Strine, Jr., Categorical Confusion: Deal Protection Measures in Stock-for-Stock Merger Agreements, 56 Bus. LAW. 919, 924 (2001) (explaining that "[the default rules of the Delaware General Corporation Law permit] stockholders to accept a tender offer and sell control of the company in the minimum number of days permitted under the federal securities laws"); Robert B. Thompson \& D. Gordon Smith, Toward a New Theory of the Shareholder Role: "Sacred Space" in Corporate Takeovers, 80 TEX. L. REV. 261, 303-305 (2001).

168 Mergers supra note 158 at 25 (describing rule \#1). 
balance of power that its law requires, ${ }^{169}$ an approach that supports the balancing analysis suggested here.

While there has been recognition of the two different judicial roles in refereeing shareholder/director governance roles, we should be careful not to claim too much clarity as yet. Development of the shareholder self-help prong in the law has been hampered because, for most of the twentieth century, economic realities did not permit shareholders to effectively use the self-help provided them under the law so there was little reason for academics or judges to spend much time developing a theory. Collective action problems effectively discouraged shareholders from using their legal power. The dominant strategy for shareholders unhappy with their managers was the Wall Street Rule to simply sell your stock. ${ }^{170}$

Even when technology and market developments made tender offers more feasible, there was concern that bidders making tender offers would prey on shareholders of target companies to the disadvantage of established companies and greenmailers would take advantage of the developing takeover market. Federal legislation via the Williams Act added disclosure and some SEC regulation of the tender office process. ${ }^{171}$ At state law, a principal judicial focus was to permit target directors to take action to protect shareholders against such abuses $^{172}$ and at the same time to bolster judicial review of defensive tactics so as to permit some bulwark against the possibility that the directors were using arguments based on protecting shareholders from raiders to effectively insulate themselves from any hostile bids. ${ }^{173}$

Subsequent developments make those concerns no longer what they were in the early 1980s. Federal rules, for example, limit two-tier coercive bust-up takeovers as occurred in Unocal. ${ }^{174}$ Institutional shareholders now occupy a much greater percentage of the shareholder census and the costs to collective action have gone down dramatically. ${ }^{175}$ Delaware judicial doctrine has recognized the additional space for shareholder decision-making in corporate governance.

\section{B. Speed Bumps in the Recognition of Shared Power}

Two historical speed bumps have slowed the development of a more coherent development of shared power governance. The first is a lingering confusion whether shareholder action by selling (tender offers) and by voting are fundamentally different in a governance

${ }^{169}$ Omnicare, Inc. v. NCS Healthcare, Inc., 818 A.2d 914, 927-29 (Del. 2003).

170 See Donald E. Schwartz, In Search of Corporate Soul, The Structure of the Corporation: By Melvin Aron Eisenberg. , 87 YALE L.J. 685, 688 (1978) (describing Wall Street Rule that unhappy shareholders sell rather than seeking alternatives such as vote).

${ }^{171}$ See Williams Act, Pub. L. No. 90-439, 82 Stat. 454 (1968) (codified as amended in scattered sections of 15 U.S.C.).

172 Cheff v. Mathes, 41 Del. Ch. 494, 199 A.2d 548, 554 (1964); Unocal Corp. v. Mesa Petroleum Co., 493 A.2d 946, 953-56 (Del. 1985).

173 Unocal, 493 A.2d at 953-56; Revlon, Inc. v. MacAndrews \& Forbes Holdings, Inc., 506 A.2d 173, 180 (Del. 1986).

17417 C.F.R. § $240.14 d-10$.

175 Edelman, Thomas \& Thompson, supra note 36, at 1397-1401. 
context. The second is a reluctance to recognize the extent to which shareholder self-help, as provided in corporations statutes, is on the same plane as directors' authority under Delaware $\S 141$. Put a different way, there does seem too quick a willingness to recognize director authority to make corporate decisions that trumps the various shareholder self-help powers. The context underlying each of these questions has changed over the last twenty-five years, both in the legal rules provided by Delaware law and in the market forces that shape what shareholders can do. Both make more sense within an approach to corporate governance that recognizes the benefit of shared and balanced power among the three different corporate constituents named in the corporations statutes.

\section{Shareholder action by tender offer vs. voting}

As outlined at the outset, the limited powers given to shareholders in corporate governance include the power to vote their shares to replace directors or to sell their shares, including selling collectively to a bidder who will thereby acquire sufficient shares to control the company. Delaware has struggled to articulate how those two shareholder powers fit with in a unified corporate governance regime, having for many years preferred voting over selling in the hierarchy of shareholder powers, but not necessarily explaining the difference.

Recall from the prior section, that unfavorable market conditions made conditions for shareholder selling unfavorable for much of the $20^{\text {th }}$ century (and the prospects for voting may not have seemed much better.) When market changes occurred, one Delaware response was to treat the two forms of shareholder action in parallel. That can be illustrated by two decisions issued by Chancellor William Allen months apart in 1988, one addressing director action to block shareholder selling into a tender offer and the other director action to block shareholder voting. In the voting case, Blasius Industries, Inc. v. Atlas Corp., the target board had increased the size of the board to block or delay an insurgent buyer from acting by written consent to gain control of the board and change the corporation's policy. ${ }^{176}$ In City Capital Associates Ltd. Partnership v. Interco, Inc., the target board used a poison pill and then a restructuring (e.g. selling off assets and borrowing money to provide a big cash payout to shareholders) to effectively block a tender offer that would have provided $\$ 74$ cash for shares that had been trading in the $\$ 40$ s. ${ }^{177}$ Chancellor Allen approached the voting and selling settings in remarkably similar fashion. In Blasius he posed the question as whether the board may validly act for the principal purpose of preventing the shareholders from electing a majority of new directors, even if the board's action was in good faith and not selfish. ${ }^{178}$ The Chancellor found that "the shareholder franchise is the ideological underpinning upon which the legitimacy of directorial power rests;" he described the Blasius context as one "involving allocation, between shareholders as a class and the board, of effective power with respect to governance of the corporation" which he distinguished from other forms of corporate action that may have an entrenchment effect-such as the stock buyback present in Unocal and other prior Delaware cases."179

\footnotetext{
176 Blasius Indus., Inc. v. Atlas Corp., 564 A.2d 651 (Del. Ch. 1988).

177 City Capital Associates Ltd. P'ship v. Interco Inc., 551 A.2d 787, 794 (Del. Ch. 1988).

${ }^{178}$ Blasius 564 A.2d at 658.

179 Id. at 660 .
} 
Later that year in addressing the poison pill defense to block shareholder selling, and applying the still new Unocal test of enhanced scrutiny (which he termed "the most innovative and promising case in our recent corporate law"), ${ }^{180}$ Chancellor Allen declared "there may come a time when a board's fiduciary duty will require it to redeem the rights and to permit shareholders to choose." 181 In finding that there was no threat as required by the enhanced scrutiny of Unocal, the Chancellor observed that "the only function left for the pill at this end state is to preclude the shareholders from exercising a judgment about their own self-interest that differs from the directors who have some interest in the question." 182 In language that echoes the legitimacy foundations of Blasius he concluded that result "would, it seems, be so inconsistent with widely shared notions of appropriate corporate governance as to threaten to diminish the legitimacy and authority of our corporate law."183

There was no Delaware Supreme Court review in either case, ${ }^{184}$ but in the years to come that court carved out separate paths in the two areas. In Paramount Communications, Inc. $v$. Time, Inc. the Supreme Court rejected the Chancellor's analysis in Interco as to what would satisfy the "threat" prong of the Unocal test as a "fundamental misconception" of Unocal. ${ }^{185}$ The flaw, as identified by the Supreme Court, was that "it would involve the court in substituting its judgment as to what is a 'better' deal for that of a corporation's board of directors." ${ }^{186}$ The result has been that a board may use a poison pill to block a bid irrespective of stockholders' desire to accept it. ${ }^{187}$ In contrast, Blasius subsequently received a more positive reception from the Supreme Court. In 1992, it accepted "the basic tenets" of Blasius ${ }^{188}$ and has applied the Blasius holding to strike down director action and let shareholders decide. ${ }^{189}$ The result was to preference voting (and more specifically only one kind of voting when shareholders vote elect directors) in terms of the degree of judicial protection to be provided by the court. In contrast a wide berth was given boards to block selling by use of poison pills and other defensive tactics.

${ }^{180}$ City Capital Associates Ltd. P'ship v. Interco Inc., 551 A.2d 787, 796 (Del. Ch. 1988)

181 ld. at 798.

182 While acknowledging that "perhaps there is a case in which it is appropriate for a board of directors to in effect permanently foreclose their shareholders for accepting a noncoercive offer... the threat here is far too mild to justify such a step." Id. at 798.

183 ld. at 800.

${ }^{184}$ Although winning an injunction against a poison pill and receiving tenders for a large majority of Interco shares, the bidders declined to go forward. The plaintiffs would have had to challenge another ruling of the chancellor that had permitted Interco's restructuring to go forward that would have dramatically changed the financial attractiveness of the company to be acquired and the bidder's financial backers, Drexel Burnham and Michael Milken were facing legal challenges of their own. City Capital Associates Ltd. P'ship v. Interco Inc., 551 A.2d 787 (Del. Ch. 1988).

${ }^{185}$ Paramount Commc'ns, Inc. v. Time Inc., 571 A.2d 1140, 1152 (Del. 1989).

${ }^{186}$ Id. at 1153.

${ }^{187}$ Air Products \& Chemicals, Inc. v. Airgas, Inc., 16 A.3d 48, 58 (Del. Ch. 2011).

${ }^{188}$ Stroud v. Grace, 606 A.2d 75, 91 (Del 1992) (accepting basic tenets but declining to apply it where it could not be said that the primary purpose of the board's action was to interfere with or impede exercise of the shareholder franchise).

${ }^{189}$ MM Companies, Inc. v. Liquid Audio, Inc. 813 A 2d. 1118 (Del. 2003)( striking down defensive measures which changes the size and composition of the board taking for the primary purpose of impeding the shareholders' right to vote effectively in impending election for successor directors). 
Explanations for the difference between shareholders acting by voting or selling have been sporadic. Delaware Supreme Court Justice Jack Jacobs, sitting by designation as vicechancellor in a 2004 case, In re Emerging Communications, Inc. Shareholders Litigation ${ }^{190}$ cited an earlier chancery case acknowledging arguments that the "tender offer form is more coercive" for the receiving shareholders than merger votes. ${ }^{191}$ That opinion stated that "a tender offer should not be treated as the equivalent of an informed vote" pointing to materially different interests at stake when tendering as opposed to voting such as their risk of being left vulnerable to being frozen out at an even lower price after a tender offer. ${ }^{192}$

As market conditions have developed over the last three decades, shareholders have moved back and forth between the two channels of voting and selling, regularly combining them, for example, by using a proxy fight to replace directors who can then act to redeem poison pills that would then permit shareholder action to accept a tender offer. ${ }^{193}$ In that context, prior distinctions between the two forms of action make less practical sense. ${ }^{194}$

In addition, Delaware courts in a series of cases sometimes grouped under the Siliconix label have used fiduciary duty to address this perceived shareholder vulnerability in tendering. ${ }^{195}$ These case hold that a fairness review under fiduciary duty is available to protect minority shareholders acting in response to a tender offer by a controlling shareholder unless certain fairness conditions have been met. These conditions, in effect would replicate the core of protections for shareholders in an arm's length merger-action by an independent directors and by a majority of minority shareholders. ${ }^{196}$ But, in addition, the controlling shareholder must

190 In re Emerging Commc'ns, Inc. Shareholders Litig., No. CIV.A. 16415, 2004 WL 1305745 (Del. Ch. May 3, 2004).

191 In re Pure Res., Inc., Shareholders Litig., 808 A.2d 421, 442-43 (Del. Ch. 2002).

192 In re Emerging Commc'ns, Inc. Shareholders Litig., No. CIV.A. 16415, 2004 WL 1305745, at *31 (Del. Ch. May 3, 2004). Shareholders receiving a tender offer lack the shareholder voter's ability to vote no and still get the transactional consideration or pursue appraisal under $\$ 262$ which doesn't include tender offers in its list of events triggering those statutory rights. 8 Del Code. Ann. tit. $8 \S 262$.

193 See Stroud v. Grace, 606 A.2d 75 (Del 1992).

${ }^{194}$ From a perspective of the practical impact on what the defensive tactics made the shareholders do differently, the defensive tactics struck down in the voting cases (which get the enhanced judicial protection) seem to cause noticeably less displacement of shareholder power than the tactics upheld in the selling cases. For example extra seats added by the board in $M M$ meant that the insurgent shareholders would face a 5-2 deficit on the board for the next governance period instead of 3-2 deficit. That is to say they were being deprived of being a larger minority but not being deprived of control (and if the insurgents were successful in passing an additional bylaw proposal to amend the bylaws to add four additional seats they would have a majority of the board immediately in either case).See MM Companies, Inc. v. Liquid Audio., Inc. 813 A 2d. 1118, 1123 (Del. 2003). In contrast, the board declining to redeem the poison pill in Interco meant the insurgent who received a large majority of shares tendered into their offer could not translate that majority into effective control indefinitely absent waging and winning a proxy contest for control of the board of directors, perhaps requiring two annual meetings.

195 In re Siliconix Inc. Shareholders Litigation, 2001 WL 716787 (De, Ch. June 19, 2001).

196 See Del Code Ann. tit. 8 §251(b) \& (c). 
agree to commit to consummate a short form merger promptly after increasing its holdings above $90 \%$, protecting non-tendering dissenter from not getting equivalent consideration. ${ }^{197}$

The Delaware legislature has now acted to treat tendering and voting as similarly able to demonstrate the shareholder consent needed for fundamental changes. The Delaware merger statute permits a new form of "intermediate merger" that can be accomplished without a shareholder vote if the acquiring party acquires sufficient shares via a tender offer. ${ }^{198}$ The recognition of shareholder action by selling reflects a significant move toward a parallel recognition of the two forms of shareholder action and together with the common law Siliconix cases should provoke the Delaware courts to rethink the traditional distinction between board defensive actions targeted to shareholder selling and those relating to shareholder voting.

\section{A sometimes judicial tendency to collapse judicial review of directors' action and shareholder self help}

The balance of power approach to corporate governance recognizes two core mechanisms providing checks on management power. Judges use fiduciary duty and accompanying legal doctrines both when shareholders assert the claim that directors/managers have misused authority given to managers to take action for the corporation and in the more particular setting where shareholders allege the director actions prevent shareholders from exercising the authority given directly to them by corporate law. The powerful lever wielded by judges under traditional application of fiduciary duty sometimes makes them vulnerable to the mentality of a carpenter with a hammer to whom every problem seems like a nail. Their inclination can be to view every problem as one calling for a decision by a judge to protect shareholders as opposed to focusing on shareholders acting for themselves.

This can be seen in the Delaware Supreme Court's Paramount v. Time ("Time") decision, another of the classic takeover cases of the 1980s. ${ }^{199}$ There the Court disapproved of the Chancery Court's approach in Interco, used in the previous part to illustrate the parallel functions given shareholders to act by voting or by selling. The Supreme Court labeled Interco a "fundamental misconception" of Delaware's standard of review under Unocal "principally because it would involve the court in substituting its judgment as to what is a better deal for that of the corporation's board of directors." ${ }^{200}$ Using a template familiar to the ordinary director

197 Some Delaware chancery decisions have called for a unified construct to address tender offer and mergers. In re Cox Communications, Inc. Shareholders Litigation, 879 A.2d 604 (Del. Ch. 2005). The Delaware Supreme Court affirmed a Court of Chancery decision that applied similar rules in a merger setting in M\&F Worldwide in 2014. While not explicitly unifying the standards under tender offer and mergers, the rules are sufficiently close so as to undercut the continuing validity of the earlier language that tender offers are not treated as the equivalent of a merger. Kahn v. M \& F Worldwide Corp., 88 A.3d 635 (Del. 2014).

19879 Laws 2013, ch. 72, §6, eff. Aug. 1, 2013 adding §251(h). A 2014 amendments extended this right to use tender offers to an interested shareholder, a context that had been excluded in the original amendment to 251(h). Fiduciary duty obligations remain for controlling shareholder for the tender offer portion of the transaction and appraisal remains available for the merger portion of the transaction.

199 Paramount Commc'ns, Inc. v. Time Inc., 571 A.2d 1140(Del. 1989).

200 Paramount Commc'ns, Inc. v. Time Inc., 571 A.2d 1140, 1153 (Del. 1989). 
action fiduciary duty context, the Court focused on limited judicial power in reviewing the board's business decision: "the precepts of the business judgment rule militate against a court attempting to appraise or evaluate the relative merits of a long term versus short term investment goal for shareholders." 201

Of course, Time was only addressing judicial review under Unocal, a form of intermediate review triggered by the perceived incompleteness in then prevailing applications of judicial review of some board actions where there is the omnipresent specter that a board may be acting primarily in its own interest, rather than those of the corporations and its shareholders. ${ }^{202} \mathrm{~A}$ different approach should apply where the primary question is not judicially enforced fiduciary duty as the only governance protection for shareholders, but where the shareholders seek to use the specific governance powers of voting and selling provided to them. But Time, a 1980s decision in the still early development of takeover jurisprudence, conflates these two protections in rejecting Paramount's argument that the action of the Time board precluded Time shareholders from accepting a control premium. ${ }^{203}$ Here the court returns to its "fundamental misunderstanding" approach to tell the Court of Chancery where the power of corporate governance lies: "Delaware law confers to the management of the corporate enterprise to the stockholders' duly elected representatives." 204

The evolution of market conditions and regulation in the time since Paramount, as discussed above, have reduced the need to rely solely on judicial use of the fiduciary duty tool and increased the space and effectiveness of shareholders using their self-help powers to vote and sell. ${ }^{205}$ The next section identifies this later development within the context of a sharedpower approach that has developed over the last three decades.

\section{Judicial and Investor Acceptance of Shared Power}

In the decades since the Time decision, courts have embraced more explicitly a balance of power approach to corporate governance. This can be seen in the specific context of each of the shareholder powers outside of litigation discussed above:206

- The Delaware Supreme Court has recognized that shareholders' statutory right to have the final say on mergers means that "the Delaware corporations law expressly provides for a balance of power between boards and stockholders;" 207

- Shareholders have the power to adopt, amend or repeals bylaws and the Delaware Supreme Court has recognized that "both the board and shareholders,

\footnotetext{
201 Paramount Commc'ns, Inc. v. Time Inc., 571 A.2d 1140, 1153 (Del. 1989).

202 Unocal Corp. v. Mesa Petroleum Co., 493 A.2d 946, 954 (Del. 1985).

203 Time, 571 A.2d at 1154.

${ }^{204}$ Id. ("The fiduciary duty to manage a corporate enterprise includes the selection of a time frame for achievement of corporate goals. That duty may not be delegated to the stockholders.").

205 See Stroud v. Grace, 606 A.2d 75 (Del 1992).

206 See Part IIIB3.

207 Omnicare, Inc. v. NSC Healthcare, Inc., 818 A.2d 918, 930 (Del 2003).
} 
independently and concurrently, possess the power to adopt, amend and repeal the bylaws"; 208

- Shareholders have the right to elect or remove directors which has been described in balancing terms: "Maintaining a proper balance in the allocation of power between the stockholders' right to elect directors and the board of directors' right to manage the corporation is dependent on the stockholders' unimpeded right to vote effectively in an election of directors." 209

- Shareholders have the right to sell their shares, as discussed in the previous section and courts have recognized the interconnectedness of voting and selling (although courts broadly permit defensive tactics to selling such as poison pills). ${ }^{210}$

Decisions in this self-help space are different than the ordinary director action fiduciary duty cases discussed above. Unlike that earlier context, the decision in this self-help space is not simply a question of a court substituting its judgment as to what is a "better deal" for that of the corporation's board of directors (which the courts have long been averse to doing under the business judgment rule), but whether shareholders would be able to substitute their judgment of a "better deal."

Of course, balanced power is not necessarily equal power and Delaware courts have interpreted director power in a way that seems skewed toward directors and away from shareholders. There is an acknowledged reluctance by the Delaware courts to use the Blasius line of cases, the most visible area upholding shareholder power. ${ }^{211}$ The Unocal lines of cases, once seen as innovative, has shrunk over time as the threat prong of its test seems to be satisfied by almost anything and the only bite in its second prong-- "preclusive or coercive"-- has been read to only cover actions that seem to completely prevent shareholder action by selling or voting. ${ }^{212}$ The effect of the combination of these two trends is illustrated by the juxtaposition of the reasoning in Unitrin. There the Delaware Supreme Court declined to apply the more enhanced scrutiny of Blasius in a context where it found the shareholders were perfectly capable of protecting themselves by exercising their right to vote in an election of directors. ${ }^{213}$ Yet in an adjacent section the Court found the shareholders sufficiently incapable of protecting themselves so as to authorize the board to take defensive tactics that made it much more difficult

${ }^{208}$ CA, Inc. v. AFSCME Employees Pension Plan, 953 A. 2d 227 (Del. en banc 2008) (recognizing shareholder bylaws cannot improperly intrude on the directors power to manage the corporation's business and affairs under Delaware $\$ 141$, but that the proposed bylaw in that case-providing reimbursement of a shareholder's proxy expenses in seeking to elect directors-did not invade the director realm).

209 MM Companies, Inc. v. Liquid Audio, Inc. 813 A.2d 1118, 1127 (Del. 2003).

210 Stroud, 606 A.2d 75.

211 Yucaipa American Alliance Fund II, L.P. v. Riggio, 1 A.3d 310, 330 (Del. Ch. 2010)('the trigger under Blasius is as extreme as the standard it invokes... this Court has noted that the non-deferential Blasius standard of enhanced judicial review, which imposes upon a board of directors the burden of demonstrating a compelling justification for such actions, is rarely applied either independently or within the Unocal standard of review." (quoting Williams v. Geier, 671 A.2d 1368, 1376 (Del.1996)).

212 Unitrin, Inc. v. Am. Gen. Corp., 651 A.2d 1361 (Del. 1995).

${ }^{213}$ Unitrin, Inc. v. Am. Gen. Corp., 651 A.2d 1361, 1383 (Del. 1995) (“it is hard to imagine a company more readily susceptible to a proxy contest concerning a pure issue of dollars.") 
for shareholders to act in opposition to directors. There should be as higher burden to characterizing shareholders as both smart and dumb in such close proximity. ${ }^{214}$

Yet even while not embracing broad rights for shareholders, Delaware courts have consistently recognized the importance of keeping all players in the game, certainly an important precondition to a balance of power approach. For example in Moran, the Delaware Court approved the board's adoption of the then new poison pill that in the time since that decision has proven to be the most consistent weapon for insiders to fend off an unwanted takeover. But the Court required that the board's later failure to redeem the poison pill must be tested by its fiduciary duty at the time of its decision not to redeem. ${ }^{215}$ The result was to preserve a channel for shareholder action - they could use the vote to replace the board which could then redeem the poison pill under the redemption feature that was (and is) common to most pills. ${ }^{216}$ Then Vice-Chancellor (and later Supreme Court Justice) Jacobs in Carmody recognized that Delaware courts are "extremely reluctant" to order redemption of poison pills so long as at least one other avenue of shareholder action remains available ${ }^{217}$ and the Supreme Court cited this with approval a dozen years later. ${ }^{218}$

This is not endorsement of that line of cases. The space left for shareholders to act has sometimes been so small as to seem invisible. The standards for applying the most intense review -Blasius-- have lacked guidance so that it seldom gets applied. ${ }^{219}$ The Unocal test, "the most attractive" alternative vehicle in the absence of Blasius ${ }^{220}$ has had its components parts eroded so that most anything satisfies the threat prong of the test ${ }^{221}$ and the only real bite of the

214 Mergers supra note 118 at 307.

215 Moran v. Household Int'I, Inc., 500 A.2d 1346, 1357 (Del. 1985).

216 See Wachtell Lipton, The Shareholder Rights Plan, reprinted in Mergers supra note 118at 229

(Describing redemption as one of 10 core features of poison pill).

${ }^{217}$ Carmody v. Toll Brothers, Inc., 723 A.2d 1180, note 17 (Del Ch. 1998) (distinguishing a statutorily permitted classified board as a defensive device that would "delay--but not prevent-a hostile acquirer from obtaining control of the board, since a determined acquirer could wage a proxy contest and obtain control of twothirds of the board over two-year period, as opposed to seizing control in a single election.").

${ }^{218}$ Versata Enterprises, Inc. v. Selectica, Inc., 5 A.3d 586, 604 (Del. 2010) (rejecting plaintiff's argument that as a particular type of poison pill was preclusive in the context of a target with a classified board, quoting Carmody's "delay but not prevent" and concluding, "The fact that a combination of defensive measures makes it more difficult for an acquirer to obtain control of a board does not make measures realistically unobtainable, i.e. preclusive").

In Unitrin, as already discussed, the Delaware Supreme Court permitted board action that effectively insulated board action against an adverse shareholder action on a merger, on the basis that shareholders retained an effective route to turn out the directors in a separate voting channel, this being the election of directors. Unitrin, Inc. v. Am. Gen. Corp., 651 A.2d 1361, 1388-90 (Del. 1995).

${ }^{219}$ Allen, Jacobs \& Strine, supra note 165 at 886. See also, Yucaipa American Alliance Fund II, L.P. v. Riggio, 1 A.3d 310, 330 (Del. Ch. 2010)("the trigger under Blasius is as extreme as the standard it invokes... this Court has noted that the non-deferential Blasius standard of enhanced judicial review, which imposes upon a board of directors the burden of demonstrating a compelling justification for such actions, is rarely applied either independently or within the Unocal standard of review." (quoting Williams v. Geier, 671 A.2d 1368, 1376 (Del.1996)).

220 Id.

${ }^{221}$ Air Products and Chemicals, Inc. v. Airgas, Inc., 16 A.3d 48, 56-7 (Del. Ch. 2011) ("Although I have a hard time believing that inadequate price alone (according to the target's board) in the context of a non- 
proportionality prong is in "preclusion", seemingly only met if all remaining shareholder channels are closed. It is not surprising that Chancellor Chandler in a context where he concluded that a target's poison pill had served "its legitimate purpose" and that a sophisticated and wellinformed shareholder base knew "what they needed to know...to make an informed decision", still felt constrained by Delaware law to let the board block the bid irrespective of stockholders' desire to accept it. ${ }^{222}$

Delaware courts have long preferred a court-centric use of fiduciary duty as the solution to governance problems and start from a point of trusting directors. ${ }^{223}$ As a result they have been slow to embrace shareholder self-help that is clearly set out in its statute and now enabled by recent changes in the makeup of the shareholder group and the incentives of shareholders to engage in governance. In this new world, the uncertainty that has characterizes the Blasius trigger and the narrowness now reflected in Unocal seems to close off too much of a balance of power that more accurately describes modern corporate governance.

There are cases that recognize shareholder self-help, such as the Chancery decision raising a Revlon claim in a takeover of the Topps Company. Then Vice Chancellor Strine found a likely Revlon violation from the target company's declining to waive a standstill agreement with a potentially higher bidder at a time when a merger vote was scheduled on a bid management preferred. ${ }^{224}$ The solution to this breach was an injunction against the standstill to permit the Topps shareholders after the provision of full information, to "rationally decide for themselves between two competing, non-coercive offers."225

This is not to say that shareholders will always get it right (just as directors or managers will not always get it right). The rise in the price of Airgas in the period after the poison pill was upheld provides ex post evidence that the company and its shareholders could have been better

discriminatory, all-cash, all-shares, fully financed offer poses any "threat" - particularly given the wealth of information available to Airgas's stockholders at this point in time-under existing Delaware law, it apparently does. Inadequate price has become a form of "substantive coercion" as that concept has been developed by the Delaware Supreme Court in its takeover jurisprudence. That is, the idea that Airgas's stockholders will disbelieve the board's views on value (or in the case of merger arbitrageurs who may have short-term profit goals in mind, they may simply ignore the board's recommendations), and so they may mistakenly tender into an inadequately priced offer. Substantive coercion has been clearly recognized by our Supreme Court as a valid threat.").

222 Id. at 57-58. ("That being said, however, as I understand binding Delaware precedent, I may not substitute my business judgment for that of the Airgas board. The Delaware Supreme Court has recognized inadequate price as a valid threat to corporate policy and effectiveness. The Delaware Supreme Court has also made clear that the "selection of a time frame for achievement of corporate goals ... may not be delegated to the stockholders." Furthermore, in powerful dictum, the Supreme Court has stated that "[d]irectors are not obliged to abandon a deliberately conceived corporate plan for a short-term shareholder profit unless there is clearly no basis to sustain the corporate strategy. "Although I do not read that dictum as eliminating the applicability of heightened Unocal scrutiny to a board's decision to block a non-coercive bid as underpriced, I do read it, along with the actual holding in Unitrin, as indicating that a board that has a good faith, reasonable basis to believe a bid is inadequate may block that bid using a poison pill, irrespective of stockholders' desire to accept it.").

${ }^{223}$ Mergers, supra note 158 at 25 (rule \#1).

${ }^{224}$ In re The Topps Co. Shareholders Litigation, 926 A.2d 58, 91 (Del. Ch. 2007).

225 In re The Topps Co. Shareholders Litigation, 926 A.2d 58, 91 (Del. Ch. 2007. 
off with the board's rejection. ${ }^{226}$ After the fact performance of Time, Inc. can be used to argue that the company and its shareholders were substantially worse off given the board decision to reject the Paramount offer. ${ }^{227}$ What is at issue here is whether Delaware's traditional approach to leave very little room for shareholders self-help still is appropriate.

The possible narrowness of Delaware's judicial balancing has shrunk in recent years as market and regulatory changes have broadened the avenues available to shareholders. Classified boards, long one of the most effective bulwarks of director' ability to forestall contrary action by shareholders, have disappeared in most large public corporations, a result that reflects market power and activism beyond the courts. ${ }^{228}$ Individual shareholders or groups have used federal access provided by Rule 14a-8 of the proxy rules to include a non-binding shareholder vote on the agenda of an annual meeting (as part of the company's proxy). ${ }^{229}$ Institutional shareholders, whose incentives to be activist in matters of corporate governance have been traditionally suspect, have voted for such proposals to the extent that many proposals gain more than $50 \%$ support of the voting shareholders. For many years, management was able to effectively ignore such votes, even when they garnered more than $50 \%$ as they were non-binding. But then proxy advisory firms such as Institutional Shareholders Services, and otherwise passive institutional investors were willing to vote against directors at a subsequent annual meeting. This combination, indirect and multi-step as it was, produced a credible threat to management leading to management's proposing and/or supporting binding action to amend the firm's articles to remove the staggered board provision. ${ }^{230}$ Shareholders now have a somewhat parallel and indirect ability to participate in governance regarding executive compensation, through the precatory voting requirements of Dodd-Frank on that topic ${ }^{231}$ and the increased willingness of institutional shareholders to use their voting power to support greater responsiveness on this issue facilitated by the activism of shareholder advisors like Institutional Shareholders Services. ${ }^{232}$ Shareholder access to director nominations is also growing through use of $14 a-8$ and the more active involvement of institutional shareholders. ${ }^{233}$

${ }^{226}$ See Lipton, supra note 146 (providing data on McGraw Hill after its "just say no" to American Express in 1979) available at http://www.wlrk.com/webdocs/wlrknew/AttorneyPubs/WLRK.23687.14.pdf.

${ }^{227}$ In re Time Warner Inc. Sec. Litig., 9 F.3d 259, 262 (2d Cir. 1993) (describing how Time stock later suffered when the company could not deliver on anticipated global alliances to pay off the large debt incurred in the reconfigured Warner deal and . had to issue additional stock in the public market driving the price down).

228 75\% of 2014 Engagements Have Already Produced Agreements to Declassify: Towards Declassification at 100 S\&P 500 and Fortune 500 Companies, Shareholders Rights Project (March 11, 2014), http://srp.law.harvard.edu/newsletters/3-11-2014_SRP_newsletter.shtml.

22917 C.F.R. $§ 240.14 a-8$.

${ }^{230}$ Mergers, supra note 118, at 230-232 (noting greater use of shareholder "persuasive" channels).

${ }^{231}$ See Randall S. Thomas et. al., Dodd-Frank's Say on Pay: Will It Lead to A Greater Role for Shareholders in Corporate Governance?, 97 CoRnel L. ReV. 1213, 1217 (2012); Dodd-Frank Wall Street Reform and Consumer Protection Act, Pub. L. No. 111-203, § 951, 124 Stat. 1375, 1899 (2010) (adding 14A to the Securities Exchange Act of 1934).

232 See Part IV. A.

233 http://www.usatoday.com/story/money/business/2015/01/27/proxyaccess-investorsbusinessroundtable-wholefoods/22234271/. 
What is important for this article regarding those changes is what institutional shareholders are doing with those broader powers. The most prevalent approach is not to use them to replace management in one fell swoop as might have occurred in 1968 or 1983, but something that clearly resembles a shared balance of power approach. Institutional shareholders have embraced a strategy of influence and dialogue, rather than conquer and burn. Activist shareholders have the ability and the votes to take over companies but they regularly refrain from the use of this power to turn out incumbent managers. Shareholders seem comfortable with divided government, a message we often see delivered in our polity. In Liquid Audio, for example, a Delaware case presenting the current state of play on Blasius, the shareholders backed insurgents for the two seats up for election on the company's staggered board but voted down a bylaw amendment that would have increased the size of the board and provided the insurgents a clear majority. ${ }^{234}$ In that case as well as others, the vote followed a divided recommendation from Institutional Shareholders Services, so it is worth examining whether the impact of proxy advisory firms on the process. The prevalence of short slate proposals by activist shareholders approach to gain representation but not control of the board, illustrating a similar preferences for shared power. ${ }^{235}$

Kahan and Rock have explored what they see as the "odd reluctance" of shareholder activist to pursue issues that have a more material impact on governance and instead pursuing matters that seem small or irrelevant, shying away, for example, from mandatory bylaw proposals that would bring additional power to shareholders. ${ }^{236}$ Their examples include shareholders activist pursuing a shareholder proposal to redeem an existing poison pill provision but would not prevent the board's future adoption and use of a poison pill with a result that the proposal would "have no impact on a company's ability to resist a bid." 237 They offer a variety of explanations including a focus on big pictures approaches such as shifting management's conception of the board to a more shareholder-centric view, or to show strength for a bigger battle or public choice theories of the roles of proxy advisers and other players that also could impact such choices. But their preferred explanation can fit into the approach suggested here. The parties recognize, as did Thurman Arnold during the New Deal, that society needs a ritual to deal with the contradiction of the social reality between the need to attack bigness and still permitting large enterprises to flourish. The end game they take from Arnold of providing space to permit the key players figure out how to make institutions serve social needs fits with a shared power approach. ${ }^{238}$

\section{Conclusion}

As market and technological development continue apace, the primacy discussion is different than a decade or two ago. Shareholders now monitor to address conflict situations

\footnotetext{
234 MM Companies, Inc. v. Liquid Audio, Inc. 813 A.2d 1118 (Del. 2003).

235 See Bratton, supra note 3.

${ }^{236}$ Kahan \& Rock, supra note 54.

237 Id.

238 Id.
} 
(courts don't have a monopoly on this) and also retain the right to speak for themselves even in the absence of traditional insider incapacity that would generate judicial intervention in director decisions. But when shareholders engage in such self-helps, they may be harming others. Modern corporate governance has evolved to preserve shareholder monitoring, but to let directors slow it down. This necessarily invokes an explicit system in which the different actors in corporate governance check each other.

A generation ago Delaware closed off the selling channel for shareholder action via judicial approval of poison pills in almost any context and shut down much of the voting channel as well. That leaves less space for shareholder action than specified by the corporations statute. In the years since, the antidote to this narrowness has come not from judicial decisions, but from market and economic forces that have empowered shareholders in ways not anticipated in the 80 s or 90 s. Activist shareholders have taken to these new possibilities, but have not used them to their maximum degree. Instead, we live in a corporate governance world in which shareholders want influence and voice, but not necessarily control. They will use any levers, including those that might be labeled ultimate control, to ensure space for a conversation that continues to take advantage of the hierarchy and efficiency of management, while subjecting that decision-making to a shared power structure in which management has the central role not absolute primacy. There remains an important role for judges in this shared power world, but it requires a greater recognition of the self-help that the statute permits shareholders and a more transparent reasoning process in the set of cases in which shareholder self-help powers conflicts with director efforts to slow down the use of that power. 